\title{
Into the Breach
}

\section{From Lake Success to Palestine: the UN Partition Plan}

\subsection{Another War}

After its initial activities in Lake Success and upon gathering information and hearing from the principal political, social and religious actors in Palestine, the UN Special Commission for Palestine went to Beirut and then Geneva to draft a final report. The path to finding a political formula that would make partition acceptable to both sides seemed arduous. Seven of the eleven UNSCOP member countries - Sweden, the Netherlands, Canada, Uruguay, Guatemala, Peru and Czechoslovakia - came together to elaborate on a territorial division that was supposed to take account of two factors: first was the demographic question, separating Palestinians and Jews and avoiding the creation of enemy enclaves within the future Palestinian and Israeli states as much as possible; the second centered on territorial continuity. The division was outlined by the vice president of the UN commission, the Swedish diplomat Paul Mohn: the Jews were to receive 62 percent of Palestine, specifically, the coastal plain from Haifa to Rehovot (including Tel Aviv and Jaffa), eastern Galilee (including Tiberias and Safed, both holy cities for the Jews) and the Negev desert; the Palestinians should receive the remaining 35 percent, including central and western Galilee (where the Palestinian cities of Acre and Nazareth are located), the region of Hebron, a holy city for Muslims and Jews, and the areas of Nablus and Jenin. The zone containing Jerusalem and Bethlehem was to constitute a corpus separatum; it would be constituted as an enclave under international control. The governor of the city under the international regime, assisted by a special police force, would be in charge of protecting the Holy Places.

The Zionist leadership did not react favorably to the idea of a corpus separatum for Jerusalem as it would be obliged to give up direct control of some of the most important Holy Places for Judaism located within the Old City. Furthermore, based on this proposal, the western part of the city, some of whose quarters were mostly inhabited by Jews, would not be administered by the Jewish Agency. The area of the corpus separatum contained about 205,000 inhabitants - a little less than half of whom were Jews and the rest Arabs (including 40,000 Christians). The municipality of Jerusalem outside of the walls contained a clear Jewish majority, while intra muros the Palestinian Arab 
population formed the majority. ${ }^{1}$ At the same time, the solution contained in the proposal for partition, namely the creation of an Israeli state in a territory that was rather more than half of Palestine, inclined the representatives of the Jewish Agency to support the project, despite not being fully satisfied with the solution laid out for Jerusalem. The same principle of territorial continuity allowed the Zionist leadership to envisage a scenario in which Jerusalem would be joined with the Negev region and the coastal zone to the south of Haifa.

Within the UNSCOP, the minority grouping - Yugoslavia, Iran, and India opted for the creation of a single, federal, binational Arab and Jewish state. The Zionist leadership was decidedly against this proposal; its implications on the demographic level were an Arab Palestinian majority within the country and strict controls on Jewish immigration. The partition proposal enjoyed the consensus of the majority of the commission's members and the Zionist leadership but faced the opposition of the Arabs. In any case, both sides within the commission agreed on certain principles - reflected in chapter 3 of the final report - relating to the Holy Places, religious rights and minorities: freedom of access and of worship were to be guaranteed and the sacred character of the Holy Places preserved. ${ }^{2}$

The main point on which the entire commission agreed was the necessity to bring the British Mandate to an end as soon as possible. The British cabinet signaled its agreement to this recommendation on September 20, 1947, some days after the UNSCOP's report was disseminated; Britain decided to abandon Palestine, without committing itself to any solution for the next stage.

1 According to the estimates formulated by the British authorities in the survey prepared for the Anglo-American Committee and based on the $193^{1}$ census, the population of Palestine grew from 75 , ooo in the census of 1922 to 1,765 ,0oo at the end of 1944. In this period, the Jewish part of the population rose from 84,000 to 554,000 - from 13 to 31 percent of the total - while the Arabs, though their proportion of the total population was falling, had increased to 1,179,000 (the Muslim community grew from 589, 00o in 1922 to 1,061,00o in 1944, while the Christians went from 71,000 to 136 ,ooo in the same period). Within the Jerusalem municipality, there were around 10,000 Muslims, 7,000 Christians and 4,000 Jews living intra muros, with approximately 95,00o Jews and 23,00o Muslims and 24,00o Christians outside the walls. See Anglo-American Committee of Inquiry, A Survey of Palestine: Prepared in December, 1945 and January, 1946 for the Information of the Anglo-American Committee of Inquiry (Washington, DC: Institute for Palestine Studies, 1991), vol. 1, 142-43 and 151.

2 UNA, United Nations Special Committee on Palestine Files: Report to the General Assembly, Documents A/364, vol. 1, chap. 3: "Religious Interests and Holy Places," September 3, 1947. See also Joëlle Le Morzellec, La question de Jérusalem devant l'Organisation des Nations Unies (Brussels: Bruylant, 1979), 63-77. 
The orientations of the majority group within the commission characterized the recommendations made in the document that it presented to the UN General Assembly on September 3, 1947. Despite strong Arab protests threatening an immediate, violent response if it were resolved to divide Palestine, the majority proposal for partition was sent for discussion by the General Assembly. On September 23, an ad hoc commission, composed of representatives of all UN member states, formed with the task to study the UNSCOP report, define the end of the British Mandate and resolve the question of Palestine's future. This new organ was in turn subdivided into three subcommissions tasked with resolving various issues in order to finalize the resolution, which would be put to the vote of the General Assembly. ${ }^{3}$

In the months following the first discussions at Lake Success to the voting on the final text, the Holy See demonstrated significant restraint. ${ }^{4}$ The plan to internationalize the Holy City, which became the Vatican's aim in the 1949-50 discussions, cannot be attributed to the Vatican. Rather, it was some European and Latin American countries which sought to protect Christian interests, with the objective to maintain a role in the Middle East, particularly given the clear danger of open warfare between Arabs and Zionists and the risk of Soviet penetration. Therefore, the Holy See refrained from taking a definitive position; in a politically unstable situation, favoring the internationalization project would have risked compromising relations with the Arab world, which strongly opposed this solution, thus endangering the Christian minority. In Jerusalem, after Patriarch Barlassina's death in September 1947, the Palestinian Latin Catholics' perception of political developments became even more complex. The confusion mingled with the uncertainties surrounding the absence of a patriarch. There was uncertainty about the next steps that Rome would take and increasing apprehension about the political and military consequences of an impending outbreak of hostilities.

On November 29, the UN General Assembly's approval of resolution 181 transformed these fears into a dramatic reality. Thirty-three states voted in favor, thirteen against, and ten - among them Britain - abstained. Thus, the United Nations gave the go-ahead to partition. According to the resolution, 55 percent of the territory of Palestine would be given to a "Jewish State" and 42 percent to an "Arab State", with the latter containing 63 percent of the

3 On the work of the ad hoc commission on the Palestinian question during the UN General Assembly in autumn 1947, see Le Morzellec, La question de Jérusalem, $78-95$.

4 For a detailed reconstruction of the wait-and-see strategy chosen by the Holy See in this phase with respect to the discussion on partition of the Holy Land, see Ferrari, Vaticano $e$ Israele, ${ }^{115} 5^{-17}$. 
existing population. The text of the resolution provided for a British withdrawal "as soon as possible, but in any case not later than 1 August 1948". The principle that a corpus separatum should be created in Jerusalem (whose boundaries were identified as Abu Dis, Bethlehem, 'Ayn Karim, and Shuffat) was reaffirmed, as was freedom of access to the Holy Places for the various religious communities.

Some narratives present the two sides as being diametrically opposite in their reactions: the Palestinians as rejecting partition and responding to the vote with violent protests, and the Zionists, on the other hand, as elated with the result. In reality, the two sides were far from monolithic. The Arab front was internally divided into various opposing factions; furthermore, the most consistent and organized army, that of Transjordan, was dependent on orders from a sovereign, King 'Abdullah, who had secretly confirmed to the Jewish Agency that he would not go through with an invasion of Palestine. ${ }^{5}$ The Zionist side, too, was split between the Jewish Agency leadership, which was keenly aware of how crucial this moment was, and paramilitary groups like Stern and Irgun, which interpreted the UN resolution as a defeat as it did not deliver possession of what they considered to be the whole "Land of Israel" (Erets Yisra'el).

The AHC announced a three-day general strike. A violent Zionist response followed all over the country. These were the first sparks of the civil war that would explode a few weeks later and consume the months that followed. Meanwhile, thousands of Arab volunteers entered the country to join the Arab Liberation Army. In this climate of imminent open conflict, Britain announced that it would withdraw from the territory by May 15 .

This phase of growing violence added to Christian anxieties. The Roman Catholic Diocese of Jerusalem spent the first Christmas after Barlassina's death without a leader and in fear. In his Christmas message on December 24,

5 In November 1947, after several secret contacts between King 'Abdullah and Golda Meir, the Hashemite monarchy and the Jewish Agency agreed to divide Palestine between themselves after the end of the British Mandate. Israeli historian Avi Shlaim has reconstructed the history of relations between the Zionist leadership and 'Abdullah in Collusion Across the Jordan, and the preface to the new, revised edition of the volume, The Politics of Partition: King Abdullah, the Zionists, and Palestine, 1921-1951 (New York: Oxford University Press, 1998), vii-xvi; see also Yoav Gelber, Jewish-Transjordan Relations, 1921-1948 (London: Frank Cass, 1997); and Mary C. Wilson, King Abdullah, Britain and the Making of Jordan (Cambridge: Cambridge University Press, 1987). For a history of modern Jordan to contextualize the connections with the Jewish Agency, see Joseph Nevo and Ilan Pappé, eds., Jordan in the Middle East: The Making of a Pivotal State, 1948-1988 (Abingdon: Routledge, 2014); Philip Robins, A History of Jordan (Cambridge: Cambridge University Press, 2004); and Kamel S. Salibi, The Modern History of Jordan (New York: I.B. Tauris, 1993). 
Pius XII called for an end to hostilities in Palestine. ${ }^{6}$ Writing to him from what he termed the "tortured Holy Land," Jallad, apostolic administrator of the Jerusalem Latin Patriarchate, thanked the pope for the prayer in his radio message, to which he and the patriarchal curia had "listened, with emotion, before setting off for Bethlehem" on Christmas Eve. ${ }^{7}$ A few weeks later, from Egypt Internuncio Hughes expressed his concern to Jallad that "the news that is coming from Palestine holds our soul in suspense". ${ }^{8}$ The apostolic administrator answered that "all contact between Arabs and Jews is impossible for the moment, and endangers life, as has happened in numerous cases". ${ }^{9}$

The first evacuations of Arabs from various parts of Jerusalem soon began. The Arab Christians would also flee en masse from the quarters of Lifta, al-Shaykh Badr, Romemah, al-Talibiyya, Talpiyot, Mekor Hayim, Bayt Safafa, al-Shaykh Jarrah, Musrara, Abu Tur and Katamon in early 1948, terrorized by Zionist attacks and the possibility of Muslim reactions, and by internal Palestinian clashes between the Husaynis and their opponents, the Nashashibis. ${ }^{10}$ Since December, about two hundred families seeking refuge had occupied the Franciscan casa nova (hospice for pilgrims) at the Jerusalem monastery of St. Saviour. ${ }^{11}$ The Haganah bomb on the night of January 5 that gutted the Hotel Semiramis, in the rich Jerusalem quarter of Katamon, which was thought to be a hideout of the commandants of Arab irregular troops, was a further blow to the Christian world in Jerusalem. The attack also made an impression on global public opinion, especially because the Spanish viceconsul was killed in the blast. The hotel - which the Mandate authorities denied was harboring Arab militias - was the property of a Christian Jerusalem family. The explosion killed some Catholics, and the event caused great alarm among the local community. Commenting on the attack, Jallad wrote to Cardinal

6 Pius XII, "Radiomessaggio natalizio ai popoli del mondo intero di Pio XII," December 24, 1947, in Discorsi e Radiomessaggi di Sua Santità Pio XII, vol. 9 (Vatican City: Poliglotta Vaticana, 1948), 391-401.

7 APLJ, LB-GB, Secrétairerie d'État, 1949-1987, Jallad to Pius XII, handwritten minute, Jerusalem, December 26, 1947, translation from Italian.

8 APLJ, LB-AG, Délégue Apostolique, 1943-1955, Hughes to Jallad, Cairo, January 14, 1948, translation from Italian.

9 APLJ, ibid., Jallad to Hughes, copy, Jerusalem, January 24, 1948, translation from Italian.

10 Morris, Birth of the Palestinian Refugee Problem, 150-56. On Palestinian fragmentation and political divisions, see Issa Khalaf, Politics in Palestine: Arab Factionalism and Social Disintegration, 1939-1948 (Albany: SUNY Press, 1991).

11 See Maria Chiara Rioli, "Catholic Humanitarian Assistance for the Palestinian Refugees: The Franciscan Casa Nova of Jerusalem During the 1948 War," in Christian Missions and Humanitarianism in the Middle East, 1850-1950: Ideologies, Rhetoric, and Practices, ed. Inger Marie Okkenhaug and Karène Sanchez Summerer (Leiden: Brill, 2020). 
Tisserant, secretary of the Congregation for the Oriental Church, that "our Christians are in agreement with the Muslim compatriots" and hence were targets "in the Jews' retaliations".12 Describing the ever-more critical situation in Jerusalem, the apostolic administrator revealed his pro-Arab sentiments: "matters are worsening; day and night one hears the fusillades and bombs," and even in the patriarchate "the shots come in through the windows". Fear of Zionist attacks mingled with the dread of Arab reprisals against European and American clergy; for them, Jallad continued, "we distribute a kind of identity card in Arabic, signed by the patriarchate and recognized by the Arab Committee, especially designed to protect those persons that could be taken by the Jews, and to permit them to access the city gates, which are closed and controlled by the Arab civic guard."13 The reality in Jerusalem was thus one of division and open conflict.

While neither side seemed to have the upper hand initially, during February and March the Arab militia carried out numerous attacks on Haganah's truck convoys. The situation in Jerusalem alarmed the Zionist leaders most. As it turned out, the Arab attacks were especially significant along the road that linked Tel Aviv and Jerusalem; in the first phase of the war the most intense fighting took place in Jerusalem, Haifa, Tel Aviv and Jaffa, the most important cities in Palestine. The horror of seeing the Jewish population of Jerusalem under threat drove the Zionist leadership to change strategy and switch to the counterattack. At the end of February, Jallad, writing to the vicar of Transjordan in Amman, Ni'ma Sim'an, described life in the city: "here, things are not improving, and just today a bomb fell nearby ... and this evening machine-gun fire was loud between the city and Mount Zion".14

Outside Jerusalem, the situation was equally dramatic. From Nazareth in Galilee, where nights where lit up "by ... the moon and ... passing bombs", 15 Antonio Vergani, patriarchal vicar for Galilee, wrote to the apostolic administrator that the condition of the priests could "already be called desperate". ${ }^{16} \mathrm{He}$ denounced the soaring price of commodities due to the difficulty in

12 APLJ, FC-AG, S. Congregatio Pro E. Orientali, 1919-1953, Jallad to Tisserant, copy, Jerusalem, January 9,1948 , translation from Italian.

13 Ibid.

14 APLJ, LB-AG, Vicariat Transjordanie, 1946-1953, Jallad to Simaan, Jerusalem, February 24, 1948.

15 APLJ, LB-AG, Vicariat Galilée, 1946-1956, Vergani to Jallad, Nazareth, March 9, 1948, translation from Italian.

16 Ibid. Antonio Vergani (1905-6o) arrived at the Jerusalem Patriarchate when he was just 15 years old. Ordained by Barlassina in 1927, he was then nominated curate of Bir Zayt, al-Salt and Bayt Sahur. In 1946, the patriarch chose him as vicar general for Galilee, a role he fulfilled until 1958. 
transporting them, and the resulting palpable increase in poverty. The parishes were also in extremis; the priests' salary was not enough to cover basic needs. Vergani therefore appealed to Jallad to increase the payments sent by the patriarchate. He did not balk from criticizing the church, asking: "Does it seem to you that the Patriarchate today honors the priests in its charge? Or does it want to drive the priests to take desperate measures?"17

As for Haifa, the most important city in Galilee, the exodus of the Arab population had been underway since the approval of partition in November 1947. In March and April 1948, after initial opposition, the AHC coordinated the transfer of Haifa's citizens to Lebanon and Syria. The Christian notables, members of the city's upper middle class, were among the first to leave. The evacuation of the Christian population was organized with the help of the Melkite bishop of Acre, Georges Hakim. The flight from the city reached its peak with the battle of Haifa on April 21-22. ${ }^{18}$ From Acre, Fr. Alberto Rock reported the arrival of "a flood of people" from Haifa. ${ }^{19}$

On the west coast, including Jaffa, the population, the vast majority of which was Arab, had been ready to flee since November 1947. The partition plan provided for the city to become an isolated Arab enclave within the State of Israel. Here too, the Christian population abandoned the city, which was besieged and subjected to heavy attacks by Haganah from February to April $1948 .^{20}$ The inhabitants mostly headed for Gaza, Egypt, Lebanon and "triangle" formed by the cities of Nablus, Jenin and Tulkarm.

Meanwhile, the situation in Jerusalem remained critical. Although the Holy Places were safe for the moment, the concern that even these most important religious structures could also be violated pervaded the minds of the patriarchal hierarchy. On March 13, a firefight damaged the great window that covered the cupola of the Church of the Holy Sepulcher. Jallad, who happened to be there at the time, was struck by falling glass. The incident made such an impression on him that he denounced it to Internuncio Hughes, suggesting

17 APLJ, LB-AG, Vicariat Galilée, 1946-1956, Vergani to Jallad, Nazareth, March 9, 1948.

18 On the exodus from Haifa, see Walid Khalidi, "The Fall of Haifa Revisited," Journal of Palestine Studies 37, no. 3 (2008): 30-58; Morris, Birth of the Palestinian Refugee Problem, 99-109; and Khalidi, "The Fall of Haifa," Middle East Forum 35, no. 10 (1959).

19 "Around 10.15 a.m., sailboats and motorboats began to arrive at Acre, full of people. What had happened? The Jews had made an assault on the city of Haifa, with twelve thousand armed men, forcing the Arab population, betrayed by the British army, to flee." Ascts, Acc, Miscellanea, Guerra arabo-israeliana, Attività del custode (July 1947-September 9, 1948), "Esodo di Haifa," typescript by Fr. Rock, chronicle for April 22, 1948, translation from Italian.

On the events at Jaffa, see Morris, Birth of the Palestinian Refugee Problem, 109-16. 
that the event was a sinister harbinger of an imminent spike in the conflict, which, he said, would spare no institution or place of worship in Palestine. ${ }^{21}$

In early March, the Arab press reported that Christian leaders in Jerusalem had met to formulate a joint protest against partition. Christian representatives had attempted mediation since January 1948 but now it seemed these efforts were being coordinated with a view to issuing a shared declaration. ${ }^{22}$ Hughes asked Jallad for more specific information about these rumors. ${ }^{23} \mathrm{~A}$ public document in the name of the Arab Christians, signed by the Catholic authorities of Palestine, would have been in plain contradiction to the policy of caution adopted by the Holy See when the United Nations voted.

According to Jallad, the proposal for an assembly of Christian representatives had been made by the AHC. ${ }^{24}$ In the weeks preceding the joint declaration on the "deplorable condition of Palestine resulting from partition", 25 the Christian leaders had met several times, with the secretary of the AHC presiding over some sessions. ${ }^{26}$ The representatives of the Latin Church were not officially involved, but a priest of the patriarchate, Ibrahim 'Ayyad, ${ }^{27}$ who had long been close to Palestinian political leaders, received a personal letter inviting him to participate in the discussion of the text. Likewise, Bonaventure 'Aqiqi, a Franciscan priest in the Latin parish of St. Saviour in Jerusalem, took part in the meetings without having been formally delegated by the custody. When the time came to sign and issue the communiqué, 'Ayyad presented a copy of it to Jallad for more detailed examination. There were some considerations that mitigated the diocesan hierarchy's misgivings at the possibility that 'Ayyad would sign on behalf of the patriarchate: according to Jallad, the Latin Church "could not fail to cooperate" with the Palestinian Arab Muslims, "and this was urgent, inevitable and appropriate" because the declaration represented "the actual general opinion of the Catholic population; and fundamentally, various elements of the population are asking for peace". ${ }^{28}$ Thus, the goal was to break the silence and hesitation of the patriarchate and of the Catholic world as to what position the Christians would take - especially the Arab Latins - and

21 APLJ, LB-AG, Délégué Apostolique, 1943-1955, Jallad to Hughes, copy, Jerusalem, March 13, 1948.

22 See asdmae, Affari Politici (1946-1950), Palestina, 4, Silimbani to the Italian Foreign Ministry, Jerusalem, January 31, 1948.

23 APLJ, LB-AG, Délégué Apostolique, 1943-1955, Hughes to Jallad, Cairo, March 4, 1948.

24 AAV, ADAGP , 9, 42, 5, fol. 454, Jallad to Hughes, Jerusalem, March 8, 1948.

25 Ibid. Translation from Italian.

26 Here, Jallad was probably referring to Imil Ghuri, secretary of the AHC.

27 Originally from Bayt Sahur and ordained in 1937, 'Ayyad (1910-2000) was appointed president of the ecclesiastical court of Jerusalem in 1945 .

Ibid. 
to stand alongside the Muslim population in opposition to partition. 'Ayyad initially signed the declaration and appended the qualification "representative of the Latin Patriarchate". 'Aqiqi did the same thing for the custody, without the formal approval of the custos. ${ }^{29}$

The text of the document, addressed to "all world religious and political bodies", took a clear stance "in unequivocal terms" against the plan for partition, judging it "a violation of the sacredness of the Holy Land which, by its nature and history, is indivisible and represents an encroachment on the natural rights of the Arabs, the people of the country". ${ }^{30}$ The declaration never directly referred to the Jewish population in Palestine or the Zionist leaders by name; but reading between the lines, the Christian representatives discounted any possibility for mediation or compromise with their Jewish counterparts and only recognized the Arabs as the legitimate inhabitants of the region.

On the other hand, there was explicit mention of the Muslims, assuring that all the Christian denominations were "in complete agreement, in principle and deed, with their Moslem Brethren in their endeavour to resist and ward-off any violation of their rights or any encroachment on their country".31 The intent of the declaration is clearly apparent in these words; it was to serve to consolidate the internal Arab (Muslim and Christian) front, reassuring and placating the Muslim element's fears and rancor toward the Christian side, which had been accused of mostly voting for partition because of the support they received from the Western powers. On this point, according to Jallad, the document had the desired effect. Writing to Hughes, Jallad - probably to justify the patriarchate's involvement in such a politically sensitive declaration - stated that "this collective declaration produced the best impression throughout the country; it calmed the spirits and increased good relations" between Christians and Muslims. ${ }^{32}$ This document also came to the attention of the consular representatives in Jerusalem, who interpreted the text for what it was: clear support for the Arabs from the Christian world of Palestine. Its impact was increased by

29 In the copy of the declaration contained in ASCTS, Gori's manuscript note reads "method of action disapproved". See Ascts, Acc, Miscellanea, Guerra arabo-israeliana, Attività di gruppi o individui (March 3-July 27, 1948), "Statement by the Committee of the Christian Union of Palestine Addressed to All World Religious and Political Bodies," text in Arabic with English translation, Jerusalem, March 3, 1948. The text of the appeal is also contained in AAV, ADAGP , 13, 42, 5, fols. 451-53; APLJ, LB-AG, Délégué Apostolique, 1943-1955, 2, and in AWCC, 301.5694.1, 4 .

3 o Ibid.

31 Ibid.

32 APLJ, LB-AG, Délégué Apostolique, 1943-1955, Jallad to Hughes, copy, Jerusalem, March 8, 1948, translation from Italian. 
the fact that Faris al-Khury, speaker of the Syrian Parliament, read the appeal at the session of the UN Security Council at Lake Success on March 24.

At the same time, in the United States, Clarence Pickett and Rufus Jones, the leaders of the American Friends Service Committee, took action with regard to events in Palestine; their requests did not favor a specific political option but instead stipulated a "treaty of God" for the city of Jerusalem. ${ }^{33}$ The two Quaker representatives sought to convince bishops and representatives of all the Christian denominations (including Thomas McMahon, the CNEWA secretary), and also Jews and Muslims, to comply with their petition. In Jerusalem, Rabbi Yitshak Herzog welcomed the appeal. On March 28, some religious leaders in Jerusalem read it as part of a day of prayer for peace in the region. Other appeals followed, from internationally recognized intellectuals like Martin Buber, Judah Leon Magnes, Albert Einstein and Leo Baeck, aimed at inducing the Palestinian and Zionist leaders to enter mediation.

From February to March, then, Christian representatives undertook various initiatives for a ceasefire, but without any real coordination. These efforts had an extremely limited impact; there was no end in sight to the hostilities. At the same time, from the first months of the conflict, these initiatives revealed the judgments and convictions emerging in the Christian world with respect to the situation.

\subsection{The Zionist Counteroffensive (March-May 1948)}

The spring of 1948 marked a turning point in the civil war. A new exodus of Palestinian refugees got underway in late March, with the displacement of around a hundred thousand Arabs. These were mostly members of the bourgeois upper middle classes of Jaffa, Haifa, the Old City of Jerusalem and the Jordan valley, who, seeing the conflict escalating, relocated to Nazareth, Nablus and Bethlehem. Most of them considered the flight from their homes to be temporary, expecting to be able to return once the political situation had stabilized; many were Christian families, including Latin Catholics. The first signs of this movement of people had been visible since the beginning of December, in the days immediately after the UN vote of November 29. The letters from priests and the correspondence of the patriarchal hierarchy make it possible

33 The AFSC was a charitable Quaker organization which, in previous decades, had allied against antisemitic persecution, collaborating with the American Jewish Joint Distribution Committee. On the Quakers' efforts at mediation in the first phase of the Arab-Israeli conflict, see Nancy Gallagher, Quakers in the Israeli-Palestinian Conflict: The Dilemmas of NGO Humanitarian Activism (Cairo: American University in Cairo Press, 2007), 29-33. 
to determine when the first departures of Latin Catholics took place, amid all the confusion of the situation from December 1947 onwards.

The fear strongly harbored by Ben-Gurion that Zionist defeats could compromise the international community's support for the formation of a state, along with concern that the Arab attacks could constitute the premise for an invasion by the armies of neighboring countries, convinced the Zionist leadership to switch to the offensive. ${ }^{34}$ There were several reasons for this change. At the end of March, Arab soldiers had launched heavy attacks on Haganah troops, which seemed to forebode an imminent defeat. After three defeats in the zone of Jerusalem, on March 27 there was an intense clash along the road at Gush 'Etsiyon, between Bethlehem and Hebron. In addition to these battles, there were daily incidents in Galilee. The siege of Jerusalem, the difficulty in supplying necessities to the Jewish quarters and the danger of a massacre of the Jewish population convinced the Zionist leaders of the necessity to change their military strategy. ${ }^{35}$

Ben-Gurion's chief concerns centered on the US position. Some declarations by President Truman in March were viewed as holding open the possibility of renegotiating partition in favor of a new mandate, this time by the United Nations, to begin on May 15. Ben-Gurion was deeply worried at the possible loss of American support. The Zionist leader feared an Arab advance, especially on West Jerusalem, and the blockade of the country's main transport arteries. Accordingly, it was necessary to prepare for change so that, when the British withdrew in mid-May, there would already be a stable scenario that favored Zionist plans. ${ }^{36}$ The mass arrival of new weapons from Czechoslovakia substantially reinforced Jewish military capacity at a crucial moment.

The principal change in Haganah's military strategy concerned its policy toward the Palestinian civilian population. When hostilities began in late November 1947, Zionist politicians and commanders did not have a clear stance on noncombatants. Up to the end of March 1948, Haganah had generally avoided destroying villages and using violence against Arab civilians. In the weeks that followed, this strategy changed in favor of increasingly resorting to the forced displacement of the Arab population.

This change was linked to the approval, in late March, of Plan Dalet, devised by a group of Zionist functionaries led by Yiga'el Yadin. ${ }^{37}$ The plan provided for

34 See Morris, Birth of the Palestinian Refugee Problem, 65-68.

35 See Morris, 1948: A History, 108-12.

36 See Morris, Birth of the Palestinian Refugee Problem, 163.

37 See Pappé, Ethnic Cleansing of Palestine, 86-126; Walid Khalidi, "Plan Dalet: Master Plan for the Conquest of Palestine," in "Palestine 1948," special issue, Journal of Palestine Studies 18 , no. 1 (1988). 
the transfer of "enemy forces" outside of the borders of the State of Israel. The crucial point was the categorization of the Arab civilian population as enemies to be expelled. The implementation of the plan opened the way to the destruction of Palestinian villages and the forced deportation of their inhabitants, and thus, to the mass exodus of refugees. It was put into action at the beginning of April with the decision to destroy the villages closest to the communication points and roads central to the control of the territory, in particular along the roads connecting Jerusalem and Tel Aviv, Tel Aviv and Haifa, and Jenin and Haifa.

Plan Dalet found its first expression at the beginning of April with Haganah's attempt to break the siege of Jerusalem (Operation Nahshon) ${ }^{38}$ and remove enemy troops and villages along the road connecting the Holy City to Tel Aviv. The battles began at two central points on this road, in the areas of alRamla and al-Qastal. On April 9, over a hundred inhabitants of the village of Dayr Yasin, near al-Qastal, west of Jerusalem, were killed by members of the Zionist forces. The village had signed a nonaggression agreement, but its proximity to the village of al-Qastal, where a battle was raging, made Dayr Yasin extremely important from a strategic perspective. The violent massacre of April 9 did not spare women and children. The entire village was effectively destroyed, its buildings blown up. The response to the Dayr Yasin attack was immense, including in the Christian world, where the fear of additional massacres increased. ${ }^{39}$ Haganah's new offensive strategy, implemented through a widespread deployment of force, had produced results. The subsequent battles concentrated in the area of Mishmar ha-'Emek; the Arab villages around this kibbutz were razed to the ground, and the inhabitants fled or were driven away. Many refugees sought safety in the Shifa'amr area, but in late April, they were forced to abandon that village.

The cities, too, were the scene of battles; the first to fall was Tiberias, which, up until a few months previously, had numbered four thousand Arabs and six thousand Jews. Between April 9 and 11, the conflict became ever more violent. On the night of April 16, Haganah launched a decisive attack. In the days that followed, the Arab inhabitants who had not already fled were transferred to

38 See Nathan Krystall, "The Fall of the New City, 1947-1950," in Tamari, Jerusalem 1948, 95-96.

39 For contemporary observers, the events at Dayr Yasin constituted a veritable watershed in the general perception of events in Palestine, and the Christian representatives did not remain indifferent. In October 1948, in a long memorandum addressed to Pius XII, Custos Gori stated that the massacre of Dayr Yasin was the event that had accelerated the flight of the Palestinians from their own homes. AsCTs, Acc, Carteggio, Segreteria di Stato, "Pro-memoria sulla Palestina presentato dal P. Custode di Terra Santa al Santo Padre Pio XII," Rome, October 8, 1948. 
Transjordan or in the direction of Nazareth. The Latin Catholics were also expelled. The parish of Tiberias, which had existed since $193^{2}$ and was operated by the Franciscans, no longer had any congregants and decided to close, while the casa nova sustained damage.

Haifa, too, was targeted in the Zionist assault. The situation came to a head with the AHC's decision to favor the evacuate the city's Palestinian civilians, and the Jewish Karmeli brigade's implementation of Plan Dalet in the city, with the objective of expelling the Arab population. On April 21, after a series of attacks from both sides, the British troops abruptly abandoned their post in the city center. The rush to occupy their vacated positions led to a pitched battle. Haganah troops, well-organized and well-armed, faced the disorder of the Arab militias. The bombardments and the contradictory announcements by the Arab Committee drove the population of Haifa to flee the city in the days that followed. Tens of thousands of people left their homes. The number of congregants of the parish of Haifa, which had existed since 1831 and was operated by the Carmelites, was drastically reduced. Thousands of refugees many of them Christians - made for the cities to the east, especially Nazareth. In late April and early May, the city's only Franciscan monastery took in hundreds of families.

Following the Zionist conquest of Haifa, the war shifted to Jaffa, the important port in Palestine. The city was already partially emptied of inhabitants, who had fled since the start of hostilities in December 1947. News of the events in Tiberias and Haifa led to another flight. The Zionist assault on Jaffa, which began on April 25, was initially directed at the quarter of Manshiyya. This was followed by a heavy attack that lasted until April 27 and resulted in the departure of thousands of people. Concerns in London that there would be a repeat of an exodus of the scale of that of Haifa or a massacre like the one at Dayr Yasin obliged the British army to take military action to break the Jewish siege. A nonbelligerence accord was established, which only lasted until mid-May, when Jaffa was occupied by Zionist forces. Here too, the Franciscan parish, founded in 1717 , saw a strong decline in the number of congregants, but it remained open.

The news on the battles underway in Tiberias, Haifa and Jaffa, and reports on the situation at Nazareth, which spread like wildfire from one part of Palestine to another, fueled the flight of terrified populations. The refugees that left the coastal plain and the north primarily moved eastward, especially toward the area of Nazareth and the cities of Jenin, Tulkarm and Nablus.

In correspondence with Jallad, Vergani revealed his growing concerns for the situation of the refugees and the uncertain evolution of the conflict. On April 22, the priest wrote to the apostolic administrator that 
life was becoming constantly more difficult here; already there are 15,000 refugees and that number is increasing every day; after the tragedy of Tiberias, now it is the turn of Haifa. Where will it all end? Provisions are becoming ever scarcer and prices are rising all the time; one cannot find anything at the market anymore, except for weapons and ammunition ... On Monday I was at Shifa'amr, which is the most dangerous place here, for now ... I'm afraid that if the Arab leadership does nothing decisive in the next days, now, within ten days, the inhabitants of Shifa'amr, Turan, Cana, al-Rayna, Macalul, Mujaydil, Jaffa of N[azareth] will all flee here to Nazareth, together with their priests and nuns. May God help us. Let us pray in turn. ${ }^{40}$

While communications became increasingly difficult in Galilee, news of new church appointments came from Rome. On April 24, Pius XII appointed Apostolic Delegate Gustavo Testa as regent of the Latin Patriarchate. In this way, while the future of the patriarchal see remained unclear, its leadership was temporarily merged with that of the Apostolic Delegation in Jerusalem. Furthermore, the pope appointed Jallad titular bishop of Menois and vicar general of the patriarchate.

The urgency in appointing a leader for the diocese, notwithstanding the vacancy in the patriarchal see, was due to the dramatic changes experienced by the local church, and not only affecting the villages and cities where the principal battles of the Arab-Israeli conflict were taking place. Indeed, the arrival of refugees transformed life in the parishes in the months preceding the scheduled date for the end of the British Mandate on May 15. Some churches lost all their parishioners, who had fled the fighting and their destroyed villages, while others were populated with new congregants arriving from various parts of Palestine.

The upheavals in the daily reality of Palestine fueled the concerns of the clergy, as reflected by Domenico Veglio, a priest in Lydda, an important junction on the road between Tel Aviv and Jerusalem. His letters to Jallad clearly reveal the anguish of the Christians and their sense of impending doom. They highlight how the Christian population, too, expected to be displaced or have to flee at any moment: "here on the plain matters are worsening. A general panic pervades the inhabitants, since it is quite possible that one day the Jews

40 APLJ, LB-AG, Vicariat Galilée, 1946-1956, Vergani to Jallad, Nazareth, April 22, 1948, translation from Italian. 
will attack the Arab villages with cannons and aerial bombs. This has already happened in some places ... whoever can, leaves". ${ }^{4}$

In villages where the patriarchate's missions were active, priests and clergymen were faced with the question of whether they would stay or leave in the event of an attack. Another question concerned the future of the patriarchal institutions, especially schools: should they be closed? And in the event of an enforced closure, how should the priests behave toward the teachers?

The priests, then, were looking for precise guidance on how to respond and what action to take should the Zionist forces arrive, which was deemed imminent. And they wanted money. If the aid supplies from Rome and the CNEWA were delivered at all, they were very slow in arriving because of lengthy checks at the port of Tel Aviv and blockades on transport. Moreover, the patriarchate had little to spare in terms of funding.

In the run up to May 15, the apprehension increased about the impending British withdrawal. Arab villages continued to fall, fueling the refugee flow. The Zionist forces consolidated their control of the villages in eastern Galilee and conquered the city of Safed during Operation Yiftah. In early May, Zionist troops arrived at Baysan (Bet Shean), an important town with a Latin Catholic community. The village was bombarded on May 12. In the days that followed, the inhabitants who had not yet fled were expelled; the Christian minority headed for Nazareth. The priest, Hanna al-Nimri, forced to leave the village after the population was expelled, was taken prisoner, but in late May, he managed to head to al-Husn, Transjordan, where his family lived. The Latin parish of Baysan, which was founded in 1920, thus ceased to exist.

From the humanitarian perspective too, the population was in extremis. Jerusalem had been under siege for some weeks and expected a further escalation of violence. Jallad, in despair, wrote to the internuncio: "We are cornered, and I do not know if we will manage to make some impression; I have suggested to the Vicar of Amman to be able to pay the masters to make some loan little by little; I do not know if he will be able. The воxes of SUPpLies are blockaded at Tel Aviv!!!"42

Meanwhile, Jerusalem was filling up with refugees. In the city, "the inhabitants of the quarters outside the walls are taking refuge within the walls; in the Patriarchate, too, we have several poor families ... The future is very obscure and not very reassuring." ${ }^{\text {43 }}$ Religious communities whose buildings had been

\footnotetext{
41 APLJ, Paroisses, Lydda, Veglio to Jallad, Lydda, April 20, 1948, translation from Italian.

42 AVv, ADAGP , 9, 42, 5, fol. 455, Jallad to Hughes, Jerusalem, May 5, 1948, translation from Italian, capitals in the original.

Ibid.
} 
occupied or destroyed took refuge in the seat of the patriarchate within the Old City, near Jaffa Gate. The Carmelite priests of Katamon also moved into patriarchal structures after the quarter was the target of a Haganah attack that led to the Zionist occupation of the area on May 1.

Church administrative buildings were also hit. When the palace of the Apostolic Delegation on Mount Zion was bombarded, Testa was forced to abandon his palace and take refuge in Bethlehem and Amman. ${ }^{44}$ The attack on the delegation profoundly affected the mood among the patriarchal hierarchy; no one felt safe anywhere anymore, especially in Jerusalem.

\subsection{May 14-15: Two Days, Multiple Narratives}

Just days before the scheduled British withdrawal on May 15, on May 12-13, Jaffa, which had been subjected to extensive bombardment, fell to Zionist troops. Chaos ensued. Among the Catholics in Palestine, both members of the hierarchy and simple parishioners, the sole remaining hope was for the Holy See to intervene in defense of the Christian refugees and of those who, although they had stayed in their homes, were terrified at the possibility of further battles and expulsions. There was also great concern about the protection of Jerusalem and the Holy Places. As Jallad made clear to Cardinal Tisserant, "we are blockaded and without mail; we cannot communicate with the missions ... The situation is deteriorating ... The inner part of the City is full of refugees from the outer part of the City; we have them in the Patriarchate too." ${ }^{\prime 5}$ Regarding the movement of the population, "Refugees from Jaffa and Haifa have entered Transjordan and the villages of Palestine; our houses and schools are open to refugees. The future is menacing." ${ }^{46}$

Jerusalem's religious orders received civilians of all faiths; the White Fathers accommodated over two hundred people, Palestinian Christians and Muslims, who had had to abandon their quarters when they came under attack. The Melkite seminary of St. Anne was occupied by displaced families. ${ }^{47}$ The Fathers of Sion, in particular, took in Jews fleeing Arab bombardment.

44 The attack on the Apostolic Delegation occasioned the loss of part of its documentary archive. A note inside the archive of the Apostolic Delegation, deposited in the AAV, states that the cards relating to the administration of Valerio Valeri were not present in the trunk or the two suitcases in which Hughes placed the documents to protect them during the Palestine War; perhaps they were forgotten in the palace and then destroyed by Transjordanian or Israeli troops. AAV, ADAGP , 1, 1, 2, fol. 38 .

45 APLJ, FC-AG, S. Congregatio Pro E. Orientali, 1919-1953, Jallad to Tisserant, copy, Jerusalem, May 4, 1948, translation from Italian.

46 Ibid.

47 See Amgma, GEN 375, Maison Mère et Annexes Jérusalem (2): Correspondance reçue de Jérusalem (1947-53), doc. 375049, Portier to Durrieu, Jerusalem, May 4, 1948. 
As the fighting in Jerusalem became ever more violent, the Fathers of Sion in Ratisbonne Monastery, located next to the Jewish Agency building, in the Rehavyah neighborhood, opened their doors to around three hundred Jews who had been left homeless. ${ }^{48}$ In particular, the priests received civilians from the 'Etsiyon block, which had been attacked by the Arab Legion earlier that month. The monastery also put its own well at the disposal of the local inhabitants, at a time when water had become scarce in Jerusalem.

Events in the middle of the month marked a new turning point in the conflict. On the afternoon of May 14, the entire Zionist leadership, with the exception of Chaim Weizmann, met in Tel Aviv Museum. Ben-Gurion took to the podium to read the declaration that would mark the official founding of the State of Israel. After referring to the biblical origins of the Jewish people and their ties to the "Land of Israel" and summarizing the history of Zionism, Ben-Gurion focused on the theme that another Shoah must never he allowed to happen, and concluded by declaring that the State of Israel had been born. The news was accompanied by the near-immediate recognition of the new state, on the same day, by the United States and the Soviet Union. While the Jewish population celebrated, Ben-Gurion was conscious that the Arab reaction would be immediate and that the founding of Israel would lead to a new escalation of conflict.

At the end of April, the leaders of the Arab League countries, established in 1945, had met in Amman and agreed on the invasion of the new state. The attack by an Arab League coalition composed of armies from Transjordan, Egypt, Syria, Iraq and Lebanon, with two contingents from Saudi Arabia and Yemen, got underway the day after Ben-Gurion's declaration. As the Arab armies entered the country, the battle in Jerusalem flared up. At the moment that the British withdrew, the 'Etsiyoni brigade launched Operation Kilshon, with the objective of occupying the Arab quarters within the Old City. ${ }^{49}$ On the morning of May 15, Israeli troops occupied the Assumptionist monastery of Notre-Dame de France, the convent of the Sisters of Mary Reparatrix, and the Italian and French hospitals. Most of the Reparatrix sisters initially

48 See "Refuge at Ratisbonne," Palestine Post, September 12, 1948. An account of these weeks is contained in a letter from a Jewish couple, Gisèle and Shlomo Arazi, in which they wrote: "The last six months in Jerusalem have been terrible, and it is a miracle of the good Lord that we have all escaped, for hundreds of our friends in the City have fallen, women and children ... St Peter of Sion has some scratches and scars that show that we were in a battlefield ... Hundreds of refugees are living with them [the priests of Notre-Dame de Sion], who have lost their homes." AIY, 2686, Père P. de Condé, Gisèle and Shlomo Arazi to Fr. de Condé, copy, Tel Aviv, November 3o, 1948.

See Morris, 1948: A History, 162-63. 
took refuge in the patriarchate and then in the convent of the Sisters of Notre-Dame de Sion, while the rest found quarters in the French hospital, where the Assumptionists had also taken refuge.

The next day, the Israeli army launched an offensive on the Old City. Fearing the loss of such a crucial area as the Old City, which contained important Holy Places and religious buildings, King 'Abdullah sent a new contingent. The battle that followed was the fiercest yet, with the Old City and the Jewish Quarter coming under heavy bombardment. On May 18, the Israeli troops occupied some religious buildings on Mount Zion: the residence of the Apostolic Delegation, the abbey of the German Benedictine monks at the Dormition, the Franciscan monastery, and the Comboni Missionary Sisters convent. The Israeli combatants fired on the city from these positions. ${ }^{50}$

In the days that followed, the fighting remained intense, and on May 28, the Arab Legion got the upper hand and succeeded in conquering the Jewish Quarter of the Old City. The violent clashes claimed many civilian victims and damaged numerous religious buildings inside the walls, including the Church of the Holy Sepulcher. Some patriarchate priests and clergy from several other congregations were also wounded or killed in the fighting.

Haganah's occupation of some religious buildings fueled the anti-Jewish resentment of various members of the Latin Church, especially those of Arab origin. Jallad presented the battle in Jerusalem as an example of the Arabs' respect for Christians and the Holy Places, whereas he saw the Israelis as showing disdain for the Christian world and its symbols, including the Vatican flag. Writing to Sim'an, the vicar of Transjordan in Amman, he described the events of those days from the patriarchate's palace. Jallad hastened to affirm that the Arab troops had avoided the destruction of Jerusalem: "The Holy City, within the walls, has been the target of continuous fire from the Jews, and, had the Arabs not arrived in time to defend it, it would have been destroyed by the Jews." ${ }^{n 1}$

$5^{\circ}$ See APLJ, $L B-A G$, Vicariat Transjordanie, 1946-1953, Jallad to Sim'an, manuscript letter in Arabic, Jerusalem, May 28, 1948 and AAV, ADAGP, 13, 55, 10, fols. 384-85, "Informazioni prese dalla lettera del Rev.mo Mgr. Gélat scritta al Vicario Latino di Amman, in data 28 maggio 1948," Amman, May 30, 1948. Sim'an responded to this letter the next day, updating Jallad on the situation of the Christians in Transjordan.

AAV, $A D A G P, 13,55$, 10, fols. 384-85, "Informazioni prese dalla lettera del Rev.mo Mgr. Gélat scritta al Vicario Latino di Amman, in data 28 maggio 1948," translation from Italian. In one of the reports that followed (one of the few in Arabic), Sim'an affirmed the necessity for the Catholic world to publicly acknowledge the respect displayed by the Arab troops. See APLJ, LB-AG, Vicariat Transjordanie, 1946-1953, Sim'an to Jallad, Amman, June 1, 1948. 
On the other side, Jewish leaders appealed to the pope to denounce the Arab attacks: in a telegram to Pius XII, Yitshak Herzog and Me'ir Hay 'Uzi'el, chief rabbis of Israel, enumerated the Arab damages against Christian churches and monasteries, appealing the pontiff to "do put end [to] these incredible barbarities". ${ }^{2}$

Despite the heavy losses it suffered in Jerusalem, in late May Haganah recorded a series of victories in the course of Operation Ben-Ami, aimed at annexing western Galilee to the new State of Israel. On May 18, there was an assault on the city of Acre, where some of the refugees who had fled Haifa had taken refuge. The attack on Acre caused a new wave of evacuations and violence. The city's parish, operated by the Franciscans since 1692, also suffered damage and was left with only a few congregants. The almost daily entries in Franciscan Albert Rock's chronicle of the time ${ }^{53}$ describe a Palestinian leadership in disarray, ${ }^{54}$ a sense of betrayal on the part of the Arab population, an attempt at mediation by various clergy together with some shaykhs and notables, who ran the risk of being branded as collaborators by their own side, ${ }^{55}$ battles and the surrender of Acre.

The third objective in this phase of combat, after Jerusalem and Galilee, was Latrun. The strategic centrality of these two cities was due to the importance the Arab Legion placed on controlling the road between Tel Aviv and Jerusalem. The goal was to blockade the supply of arms to the Zionist forces, which were trying to occupy Jerusalem.

\subsection{The Bees of Latrun}

Situated in a small village midway between Tel Aviv and Jerusalem, near ancient Emmaus, the Trappist monastery of Latrun stands on a hillside atop of

52 ASs, ACAES, Pio XII, 2, Palestina, 5, fols. 465-66, May 29, 1948.

53 Ascts, Acc, Miscellanea, Guerra arabo-israeliana, "Cronaca di Acri, P. A. Rock (1948)". This is an extremely interesting source, but one that requires careful treatment. The typescript transcription in Italian probably dates from after the events, even if the text seems to have been composed in 1948-49.

54 "Also our mayor, who spoke for resistance enthusiastically yesterday, has taken off, well supplied with grain and money." Ibid., chronicle for May 11, 1948.

55 "Around 5 p.m. they asked me again to go to the Jews. I refused. There is already talk in the city of betrayal on the part of those who are willing to hold discussions with the Jews. It was difficult for me to bear this silence ... Around 6 p.m. A huge crowd gathered by the monastery wanting to go to discuss with the Jews. I went in search of the only shaykh remaining in the city, Musa effendi Tabari, and brought him to the monastery ... in the end a commission was formed for the discussions, comprising me, al-Shaykh Musa; Mithqal Jarrar, 'Abd al-Rahman al-Musulmani al-Husayni; Ahmad 'Abduh, Ahmad Idilbi, and Ahmad al-'Adluni." Ibid., chronicle for May 17, 1948. 


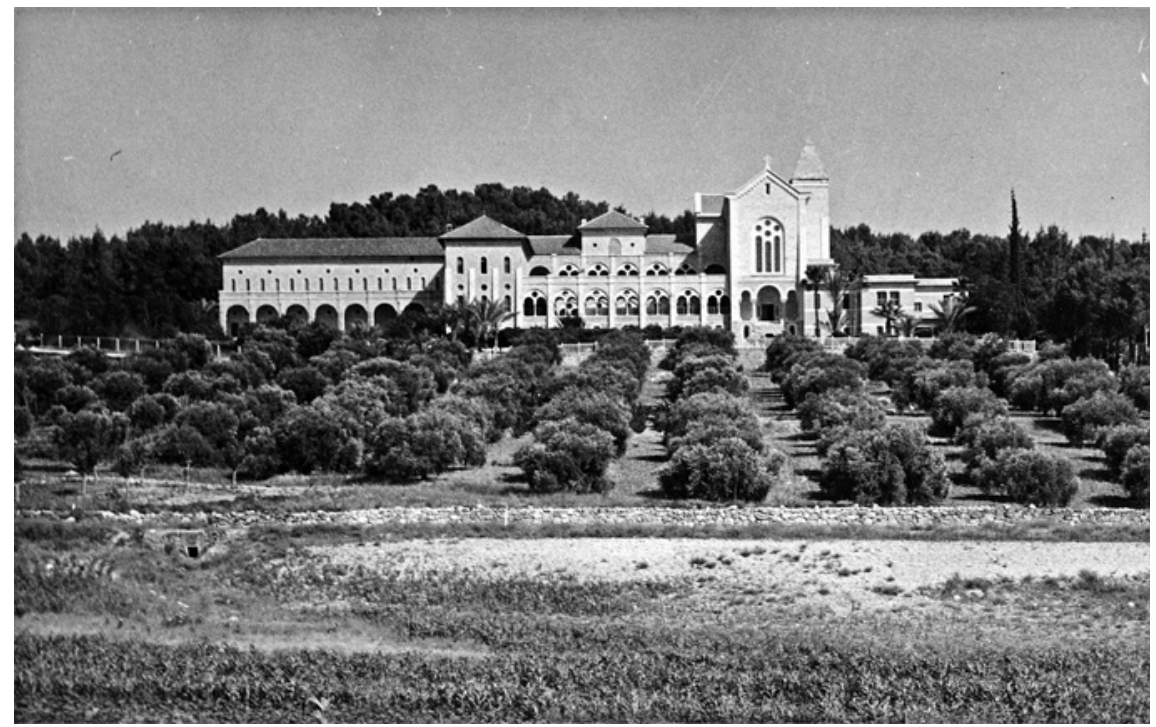

FIGURE 2.1 Trappist Monastery, Latrun

APLJ/AEBAF

which is a crusader fortress (fig. 2.1). Like numerous other congregations, the Trappists had arrived in late the nineteenth century. Construction of the modern monastery was completed in 1925. The place had strategic value because of its geographical location; during the British Mandate it was augmented by a detention camp placed at the gate to the monastery and a police station, both built by the British. During the Second World War, the monks took it upon themselves to provide religious services to the soldiers stationed in the area. They also offered aid and spiritual comfort to the Italian and German clergy interned in Rafat and al-Qubayba.

Since the beginning of the war, the clergy in the area had been conscious that, were the conflict to spread, the village and the abbey would become targets. With the announcement of the British withdrawal, the community spent three weeks on high alert. Haganah battalions targeted the monastery with artillery and succeeded in occupying the abbey and the surrounding grove, with the conquest of the whole village as the ultimate objective. In late 1947 and early 1948 , incidents multiplied between Arabs and Jews in the area. ${ }^{56}$

$5^{6} \quad$ The events around the monastery of Latrun during the first Arab-Israeli war are described at length in a memoir titled Histoire de l'abbaye d'el-Latroun par un moine d'el-Latroun (1890-1960), conserved in AIY, 2686-2, Latroun 1890-1965. Chapter 11 contains a text dated September 1, 1948, that practically comprises a diary of the events of the preceding months of war. 
However, despite signs of an imminent escalation of the conflict, the abbot of Latrun noted that "life continues, the community remains calm, construction work continues in slow motion ... We take precautions, but we put ourselves in the hands of divine providence. ${ }^{57}$

The situation worsened in April, as the belligerents concentrated their troops around the monastery. The fighting on April 20 cut the road between Jerusalem and Latrun. Eight days later, the British abandoned the detention camp, located a kilometer from the monastery, while Arabs and Jews raced to raid it. At the beginning of May, the Zionist forces erected defenses in the area, surrounding the abbey and sowing panic among the Palestinian population. On May 10, Haganah's occupation of the monastery seemed imminent. According to the monks, Haganah's conquest that day was prevented by an enormous swarm of bees that attacked the Israelis. The monks cast the episode in a providential light; spread by word of mouth, even decades later the legend holds that "bees saved the monastery", ${ }^{8}$ providing a strong symbolic image. ${ }^{59}$

Despite the deferral of the occupation of the monastery, the bombardment of it was relentless (fig. 2.2). On the afternoon of May 14, the monks noticed an interminable convoy of three hundred armored vehicles going toward Jaffa; it was the British, who had abandoned both the area and Palestine as a whole. The police station that the British army had operated was immediately occupied by the Arabs. The next day, the Zionist forces entered al-Qubayba, four kilometers from the monastery; the road to Jaffa was also blocked. On May 16, the day after the Arab invasion of Palestine, the monk's nighttime prayer for Pentecost was accompanied by fusillades and artillery. ${ }^{60}$ In the following weeks, the community found itself in the crossfire of the Arab and Israeli troops. At the end of May, the battle ended in defeat for the Israeli army, which incurred heavy losses both strategically and in terms of human life. ${ }^{61}$ Latrun would remain the greatest loss for Israel in the Palestine War of and it represented the last phase of Arab dominance in the conflict.

57 Ibid, translation from French. Paul Couvreur, a French monk, was appointed abbot of Latrun in 1937, remaining in the position until 1952.

58 Ibid.

59 Described as if it were a new "plague" of biblical memory, the invasion of the bees at Latrun represents a reversal of the story of Exodus; in the interpretation of the conflict elaborated by some Trappist monks, the Israeli troops took the role of the pharaoh's army, which should leave if it did not want to incur divine punishment, while the Arabs became the modern-day Jews, to be granted freedom and control of the "Promised Land". Furthermore, in Deuteronomy (1:44), the Amoraeans who chased the Israelites out of their territory are compared to a swarm of bees.

Ibid.

61 See Morris, 1948: A History, 224-30. 


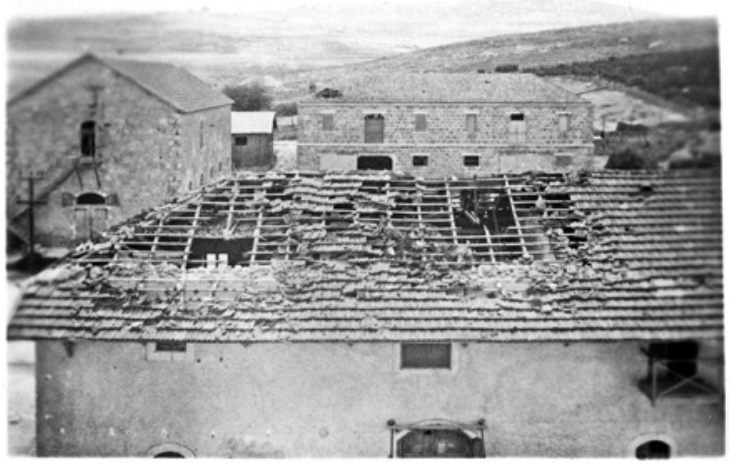

FIGURE 2.2

Damage to Trappist

Monastery, Latrun, 1948

AATL/AEBAF

In these dramatic circumstances, the monks met to consider their options. Provision was made for any monk in danger to take refuge, and a team, composed of younger monks, brought aid to the wounded and extinguished fires. Religious ceremonies in those weeks were punctuated by battles. In one account, a monk recorded the run-up to a truce that would begin in all Palestine on the morning of June 11 and was designed to last 28 days, until July 9:

Since the morning, the sick have been arriving at the dispensary. A little before 8 o'clock, the shells were raining down, the poor people were terrorized; we had to interrupt their care and put everyone in the shelter. No other option than to put them in the basement, close to the community. Some shells fell after 8 , showing how unwillingly the fighting stopped. ${ }^{62}$

In the month of June the Israeli initiatives during the ceasefire would change the fate of the conflict.

\subsection{Mediation Attempts}

Late May also saw fighting on the northern front, where Iraqi troops had been stationed since the end of April, representing the northeastern wing of the Arab Legion. On May 15, the Iraqis attacked the kibbutzim in the Jordan valley near Gesher. After alternating successes between the Iraqis and Israelis, Tsahal troops ${ }^{63}$ succeeded in driving their enemy back across the Jordan. At

62 AIY, 2686-2, Latroun, 189o-1965, memoir titled "Histoire de l'abbaye d'el-Latroun par un moine d'el-Latroun (1890-1960)."

63 Tsahal is the acronym for Tsva' ha-Haganah le-Yisra'el. 
this point, the Arab soldiers decided to go down along the eastern bank of the river. The Israelis then proceeded with a counterattack, with some battalions of the Karmeli and Golani brigades launching an offensive on the city of Jenin. The Israelis succeeded in occupying the center of the city, but a counterattack by Arab troops from Nablus forced Tsahal to retreat. The battle of June 3 left hundreds of dead, mostly Iraqis.

During the march on Jenin, the Israeli army had occupied some villages in an area that contained Latin Catholic communities, including Jalama and Dayr Ghazala. The curate of Jenin, Antun Hihi, wrote to Jallad that "after the disaster of Jenin, the center of several of our little surrounding missions, I find myself compelled to leave my position ... for at Jenin itself my residence was ... destroyed." ${ }^{64}$ The priest subsequently moved to the small parish of Burkin, southwest of Jenin, but the Israeli troops too made this village "into a fearful target". "I had to spend part or all of several nights under the trees," reported Hihi, who eventually decided to move to Nablus. ${ }^{65}$

During these latest events too, one of the most damaging aspects for the Latin Catholics in Jerusalem and throughout Palestine was the substantial silence on the part of the Holy See regarding the fighting. In a letter to Jallad, three priests - Hanna al-Nimri, Zakariyya Shumali and Bishara Farwaji - called for the pope to pronounce on "the atrocity" being committed against Christians and Muslims by the Zionists. ${ }^{6}$

Pius XII expressed himself in his encyclical Auspicia quaedam of May 1, $1948 .{ }^{67}$ Recognizing the actions being taken by the international community toward creating a new order between the nations directed at peace after the horrors of the Second World War, the pope underlined the necessity for prayer for the defeat of those who, in his reading of the political situation, were a threat to the realization of this new global asset. The encyclical continued with the proposal for a consecration to the Sacred Heart of Mary and to ask her to intercede for peace, freedom and the prosperity of the church and of the world. In this same text, the pontiff underlined the invitation to pray to the Virgin Mary for world peace and for a solution to the problem in Palestine.

The pope also dealt publicly with the Palestine War in a discourse to the College of Cardinals on June 2. "How could the Christian world look on unconcernedly, or in fruitless indignation," as Palestine was "trampled by troops of

\footnotetext{
64 APLJ, Paroisses, Jenin, Hul to Jallad, Jerusalem, September 2, 1948.

65 Ibid.

66 APLJ, Paroisses, Nablus, 1860-1950, al-Nimri, Shumali and Farwaji to Jallad, February 2, 1948, translation from Arabic.

67 AAS 40 (1948): 169-72.
} 
war and bombed from the air", Pius asked. ${ }^{68}$ However, Roman Catholic officials in Jerusalem did not consider these pronouncements in any way sufficient. What they were asking for was mediation between the two sides in order to come to a treaty, and many of them in addition sought condemnation of the aggressive actions on the Israeli side.

The papal speech determined the response of Rabbi Yehuda Leyb Fishman, Israel's first Minister for Religious Affairs, who wrote to Pius of being "deeply sensible of the importance of your eloquent appeal against the world's indifference to the bloodshed and suffering in the Holy Land", but pointed out that "ancient Jewish synagogues have not only been hit ... but have been deliberately destroyed by Arab forces", while "after the Jewish surrender in the Old City all Moslem Holy Places in Jewish controlled areas have been scrupulously respected." 69

Meanwhile within the Latin Church, Jallad's role "in expertise and loyalty," as Testa also endorsed, ${ }^{70}$ was confirmed by the Holy See with his consecration as bishop, on June 27 in the co-cathedral of the Latin Patriarchate, by Testa, who had just returned to Jerusalem for some days. The war meant the consecration had to be done "in such a hurry"; Internuncio Hughes was not able to participate, and the only other bishop present was the Melkite Bulus Salman, archbishop of Petra and Philadelphia (1932-48), together with Custos Gori and the Trappist abbot Dom Paul Couvreur (fig. 2.3). ${ }^{71}$

On the same day as Jallad's consecration, Count Folke Bernadotte, the UN mediator, proposed the basis for a peace accord to the two sides. A truce had been in place since June 1, after months of requests from the international community and the Christian world. On May 29, the UN Security Council had approved a resolution requesting a four-week ceasefire and imposing an arms embargo on both sides. The Israeli failure to take Latrun and Jerusalem and, at the same time, the hopelessness of Arab efforts to turn the conflict in their

68 AAV, ADAGP, 11, 49, 6, fols. 142-46: 145, "Allocution of His Holiness Pius XII to the Sacred College," June 2, 1948, now also in Pius XII, Discorso al Sacro Collegio nella festività di sant'Eugenio, June 2, 1948, in Discorsi e Radiomessaggi di Sua Santità Pio XII, vol. 10 (Vatican City: Poliglotta Vaticana, 1949), 115-22.

69 Ass, ACAEs, Pio XII, 2 Palestina, 5, fols. 463-64, Tel Aviv, June 4, 1948.

70 APLJ, AG, Gelat, 1948-1968, manuscript autograph document by Testa and Patriarchal Chancellor Theodor Maat reporting on Jallad's nomination as vicar general, Jerusalem, June 20, 1948, translation from Italian.

71 APLJ, LB-AG, Délégué Apostolique, 1943-1955, Jallad to Hughes, copy, Jerusalem, June 3o, 1948 , translation from Italian. 


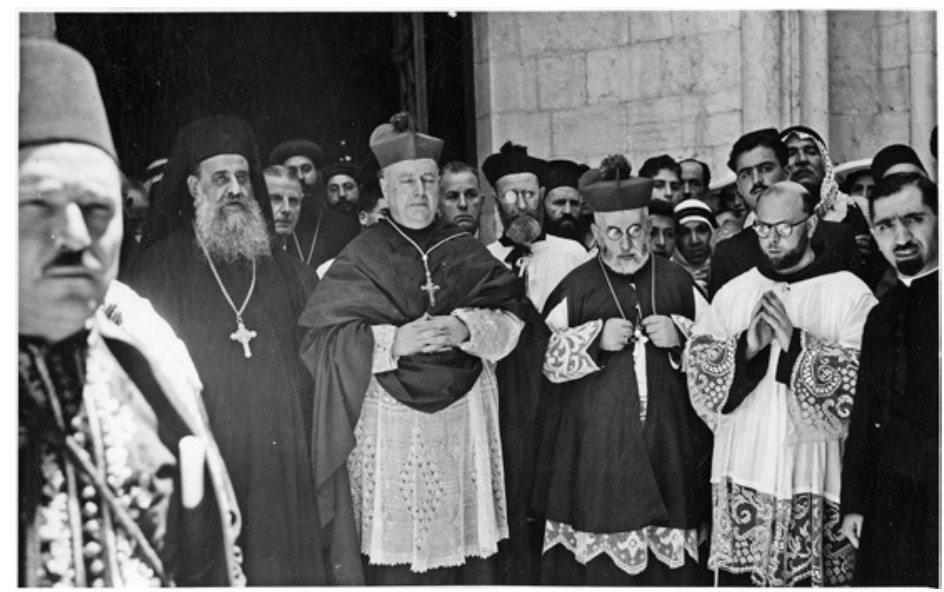

FIGURE 2.3 Episcopal consecration of Mansur Jallad by Gustavo Testa, June 27, 1948 APLJ/AEBAF

favor, forced both sides to accept the truce. Thus, at the beginning of June, the $\mathrm{UN}$ resolution suspending the use of arms went into force. ${ }^{72}$

Bernadotte worked hard to reach an agreement during the four-week truce. The basis of his text acknowledged the need for a triple recognition: the Arabs had to recognize the newly founded State of Israel; the international community had to recognize the Transjordanian conquest of territory originally seen as part of a future Palestinian state, and the UN partition plan had to be recognized as impracticable and thus renegotiated within the new parameters. Bernadotte's designs for a single, binational state did not find favor with either side.

\section{A Summer of Battles}

On balance, Israel maintained the upper hand in the first weeks after the Arab invasion; the truce served to consolidate this advantage, reinforced by the massive arrival of new arms for Tsahal troops. Despite the Israeli army's failed assault on Latrun and failure to penetrate Jerusalem, it benefitted from the internal divisions and differing objectives in the Arab camp, which became abundantly clear during the truce. On the opposite side, the Israeli

72 On the formulation of the truce, see Morris, 1948: A History, 264-67. 
political and military leadership seized the opportunity to review and reinforce their strategy and, even more importantly, they doubled troop numbers and increased their arsenal with weapons from Czechoslovakia or acquired in the United States and in Western European countries.

The resumption of hostilities did not wait for the end of the 28-day truce on July 9. Egyptian troops broke the ceasefire the day before, in an attempt to penetrate the area near the road connecting Bayt Jibrin and Majdal, in the outskirts of Hebron. As the conflict recommenced, there were several decisive fronts, especially the central line, with battles close to the cities of al-Ramla and Lydda, and the Tsahal operation in Galilee to consolidate its control in the north of the region and to occupy Nazareth, one of the symbolically most important towns of the region.

\section{1}

The Israeli Capture of al-Ramla and Lydda

Lydda, a small town about twenty kilometers from Tel Aviv, had very ancient origins. It was important for Christians because it was the location of the tomb of Saint George, conserved by the Greek Orthodox church in the village. While a Latin patriarchal mission was established in 1857 , its presence was actually more recent in origin as it had reopened in 1924 after being closed for a time. Regular religious service was only guaranteed after 1942. Domenico Veglio was the first Latin priest to be permanently based in Lydda, where he moved in early 1945. There was also a community of the Sisters of the Rosary in Lydda. During the Second World War, many soldiers, especially Poles, were detained in the town's chapel.

The town had experienced significant population growth as a result of the nearby railroad station, where trains passed through from Egypt toward the principal cities of Palestine, Lebanon, Syria, Turkey and, ultimately, the most important European capitals. The connection greatly facilitated contact and exchange between Haifa, Jerusalem and Jaffa. No less significant was the presence of two airports, one civil and the other military.

In the mid-1940s, its population numbered around twenty thousand inhabitants, comprising eighteen thousand Muslims and two thousand Christians. Of these, 250 were Latin Catholics, ${ }^{73}$ consisting mostly of parishioners native to the place and those who had moved there to work at the railroad station and airport. The mission reestablished by Patriarch Barlassina also included

73 See APLJ, LB-AG, Délégué Apostolique, 1943-1955, memorandum titled "Mission de Lydda," prepared by Fr. Veglio, July 1945. The data is also to be found in the statistics on the patriarchal parishes (updated to December 1946), contained in the appendix to the volume by Perrin, Centenaire du Patriarcat latin. 
two schools, one for boys and one for girls, which together had around 160 Catholic, Orthodox and Muslim students in 1945. Lydda was one of the poorest parishes in the patriarchate, and over time the rectory had become "a hovel", not fit for habitation even for the priest himself. ${ }^{74}$ According to Veglio, rivalry between Catholics and Orthodox was particularly strong, and the parish, fearing an increase in "schismatics", appealed to Barlassina for financial assistance, convinced that the mission had "a good future". ${ }^{75} \mathrm{Al}$-Ramla, three kilometers away, was a town with a population of about eighteen thousand. Its mission had a longer history than Lydda's. Established in 1664, it was operated by Franciscans, led by Fr. Giulio Bichi. Its school grew substantially in the 1940s, with male students increasing from 70 to 35 o. The Roman Catholic communities of Lydda and al-Ramla were located in a decidedly majority Muslim area. Veglio remarked in particular on the rivalry with the Muslims and the Christians of other denominations, voicing his dissatisfaction to Barlassina over the years on the difficulties on developing effective pastoral services.

The projects and the hopes of the priest and his community were wiped out as the fighting between Arabs and Zionists arrived. In early 1948, terror at the prospect of an Israeli attack on the village precipitated the flight of some of its inhabitants. In addition, the two towns had seen their populations increase as a result of the arrival of tens of thousands of refugees, mostly from Jaffa. The communities' fears proved well-founded. General Yig'al Alon, commander of the Palmach, the elite units of the Haganah, had used the opportunity of the truce in June and July to develop a plan to attack Lydda and al-Ramla, aiming at the military conquest of the areas occupied by the Arab Legion on the road between Jerusalem and Tel Aviv. On July 10, Operation Dan got underway, with a huge number of Israeli brigades pitched against the Transjordanian army, led by General Sir John Bagot Glubb. ${ }^{76}$ Ben-Gurion himself had ordered that the two towns be destroyed, sowing panic that would force the collapse of the Arab troops. ${ }^{77}$

Led by Lieutenant Colonel Moshe Dayan, on July 11 the Palmach began an artillery assault on Lydda, encountering no real defense from the Arab

74 APLJ, Paroisses, Lydda, typescript memorandum on Lydda by Fr. Veglio, undated.

75 APLJ, ibid., Veglio to an unknown "Eccellenza Reverendissima” from the Congregation for the Oriental Church, Lydda, July 11, 1946.

76 The recent accession and opening by the MECA at St. Antony's College in Oxford of the papers of British army officer John Bagot Glubb have facilitated new documentary-based studies, like Matthew Hughes, "The Conduct of Operations: Glubb Pasha, the Arab Legion, and the First Arab-Israeli War, 1948-49," War in History 26, no. 4 (2019), and Graham Jevon, Glubb Pasha and the Arab Legion: Britain, Jordan and the End of Empire in the Middle East (Cambridge: Cambridge University Press, 2017), esp. 104-8.

On Operation Dan, see Morris, Birth of the Palestinian Refugee Problem, 423-36. 
Legion, which was stationed some distance away from the town. According to Veglio, the buildings of the Latin Patriarchate were not spared in the bombardment. ${ }^{78}$ The Muslim inhabitants gathered in the mosque, while the Christians sought refuge in the Orthodox church of St. George. More than 25 o people were killed in the attack.

On July 12, al-Ramla was captured by the Israeli army. On the same day, a new battle took place in Lydda. This second attack was particularly fierce, with the Israeli troops firing grenades and bazookas at the village, especially the mosque. On the next day, the Israeli troops expelled the population of both towns, forcing them to march about twenty kilometers in the heat, with many children and elderly people dying on route. One estimate puts the number of deaths from the fighting and expulsion at around 1,300. ${ }^{79}$ The population expulsion added to huge number of Palestinian refugees, especially from the cities of Jaffa, Haifa, Safed, Tiberias and Baysan - about a hundred thousand people - who had previously fled to Lydda and al-Ramla themselves, and who now, after the battles of July 11-12, were forced to flee again. Many of them, including the Christian population, headed toward Ramallah and Har Efrayim, and to Transjordan..$^{80}$ Only about a hundred people remained in the town. While the Roman Catholic parishes of Lydda and al-Ramla lost the vast majority of their congregations, they did not close. In the case of Lydda, the church buildings had also been destroyed. The few dozen Christians who stayed celebrated Mass in the homes of some parishioners who lived close to the railroad station.

The conquest of Lydda and al-Ramla took on enormous importance in the evolution of the conflict, which inflicted heavy losses on the Arab side. In addition, Israeli troops also extended the corridor in the direction of Jerusalem, occupying some cities in which Latin Catholics lived. In 'Ayn Karim, whose Roman Catholic parish was served by the Franciscans, the expulsion of the Palestinian inhabitants, initiated in April after the massacre of the neighboring village of Dayr Yasin, took place at the same time as the battles for Lydda and al-Ramla. The Latin Catholic community of the church of St. John the Baptist

78 From the United States, in summer 1949 Count Luigi Criscuolo, Grand Officer of the Equestrian Order of the Holy Sepulcher of Jerusalem, writing to Léandre Girard, mentioned that he received a letter from the curate of Lydda requesting funds for the mission destroyed during the war. APLJ, Paroisses, Lydda, Criscuolo to Girard, New York, August 23, 1949.

79 See Henry Laurens, La question de Palestine, vol. 3, L'accomplissement des prophéties (19471967) (Paris: Fayard, 2007), 144-45.

8o See Pierre Médebielle, Birzeit. Histoire d'une localité et de sa mission latine dans la montagne d'Ephraïm (Jerusalem: Patriarcat Latin, 1976), 85-87. 
was reduced from 256 to around ten, mostly women and elderly. ${ }^{81}$ While these events were underway, the Israeli offensive moved to attack one of the most important centers of Galilee and of Christianity: Nazareth.

\subsection{The Warfare in Nazareth}

For months, thousands of refugees had fled to the town of Nazareth. The immeasurable growth of its population made it difficult to provide aid to the refugees and increased fears of an attack by Zionist forces. From that spring, the news reaching Galilee had become particularly dramatic. Vergani wrote to Jallad that "today Nazareth has more than thirty-three thousand inhabitants - and those are the registered ones; and every day there are hundreds and hundreds that arrive from all directions". ${ }^{82}$ The situation came to a head after the truce in mid-July 1948, when the Israeli Operation Dekel targeted the Arab Legion in western Galilee, where the majority of its troops were stationed, and in particular, the Nazareth area.

The attack on the town was preceded by the occupation of some surrounding villages. Some of these had Christian inhabitants and Latin Catholic parishes. One was Shifa'amr, a mixed village inhabited by Muslims, Druze and Christians of various denominations. The Latin mission was founded in 1879; in 1946, the small community numbered ninety congregants. There was also a religious community of the Ladies of Nazareth, which ran a school in Shifaamr attended by students from various rites. In those wartime months, the priest, Fr. Marc Dalmedico, a convert from Judaism, feared he would fall victim to Arab attacks. ${ }^{83}$ Here too, the population had been on high alert since the outbreak of the Arab-Israeli War; since April, hundreds of Palestinian refugees from western Galilee had poured into the area around Shifa'amr. Israel's aim to occupy the village was part of its overall Nazareth mission.

The fate of Shifa'amr was linked to an Israeli-Druze pact, with the village at the center of a surrender negotiation between the Druze leadership and the Israeli military command. ${ }^{84}$ A Druze-Zionist alliance was established in the

$81 \quad$ ASCTS, Status descriptivus, 1951, 99.

82 APLJ, LB-AG, Vicariat Galilée, 1946-1956, Vergani to Jallad, Nazareth, April 22, 1948, translation from Italian.

83 As Vergani wrote, "Fr. Marc [Dalmedico] is very excited; the children insult him in the street and he can no longer leave the house; he has already packed his things and requests to be replaced, saying that in any case, he can do little for the parish, given his origins, in the current predicaments and general state of excitement." Ibid.

84 The events surrounding the conquest of Shifa'amr by the Israeli forces are among the most studied in the historiography of the first Arab-Israeli war. See, in particular, the fundamental contributions of Laila Parsons, The Druze between Palestine and Israel, 1947-49 (London: Palgrave Macmillan, 200o), and "The Druze and the Birth of Israel," in The War 
expectation that the Druze would respond to the Israeli attack with a feigned defense that would enable a swift capture of Shifacamr by Tsahal forces. In exchange, the Israeli army undertook not to expel the Druze citizens. The agreement was implemented; Shifa'amr was conquered bloodlessly on July 13-14, although bombs struck the convent of the Ladies of Nazareth, damaging it. The small Latin Catholic community remained in the village.

Mujaydil was another village that was attacked in the course of this operation. Like Shifa'amr, it had a Latin Catholic component to its population, which had a local parish, opened in 1904 and operated by the Franciscans. Before the conflict, the village had a population of about two thousand people, more than half of them Muslim, with the rest comprising Orthodox and Latins. During the war, control of Mujaydil enabled the Arabs to command the road that connected some important Jewish colonies, especially between Nahal and al-'Afula, fundamental for east-west communications of the troops moving toward the conquest of Nazareth. In mid-July, Zionist forces attacked and occupied Mujaydil. Writing after the events, Italian religious reported that the village had under bombardment for some weeks and other religious buildings had also been hit. ${ }^{85}$ The Israeli attack of July ${ }^{-1} 5^{-16}$ destroyed large areas of Mujaydil. Its inhabitants were expelled; some of them went to Nazareth, where they were received by the Franciscan casa nova in the city.

Nazareth itself was the Israeli forces' next objective. The news from the neighboring villages terrorized the population of the town and alarmed the notables. The Israeli command was aware of its symbolic importance for the entire Christian world, and they knew that they could not deploy the violence that they had used on neighboring villages. Ben-Gurion himself gave the order not to strike the religious symbols of Nazareth.

Both sides - the Israeli military and the Arab notables - shared fears of a bloody battle, and the evident superiority of the Israeli forces over a volunteer corps mustered by the increasingly overstrained troops of the Arab League drove the two sides to seek an accord. On July 16, Zionist forces entered the

for Palestine. In her studies, Parsons deconstructs Morris's thesis on the Israeli-Druze accord; for a presentation of Morris's interpretation, see Morris, Birth of the Palestinian Refugee Problem, 415-18.

85 "On the night of July 3-4, a bomb dropped from a Jewish airplane was let fall on our school building"; in the days after July 16, Israeli soldiers visited the Sister and the priest of Mujaydil in search of weapons, while "there were a few Arabs from the village, old and sick, and ... nothing else". The soldiers damaged and requisitioned "all the things deposited there by our Christians and by some Muslim family ... wardrobes, mirrors, mattresses, domestic utensils, provisions." AsCTs, Acc, Miscellanea, Guerra arabo-israeliana, Rapporti di religiosi (August 12, 1948-January 22, 1949), Fra Pietro Tusa and Sr. M. Sebastiana, Mujaydil, August 12, 1948, translation from Italian. 
town. The surrender was almost immediate, with scores of inhabitants abandoning their homes in panic. The Christian clergy stayed in Nazareth, as did most of the refugees who had fled there from the fighting. The Franciscan casa nova was the primary recipient of refugees; since the eve of the surrender of Nazareth and on the day itself, the monastery opened its doors to thousands of people of any religion. "In less than two hours" the Franciscan school was emptied of furniture to make room for about thirty families. Apart from two Christian families who arrived that night from Tiberias, all the rest were Muslim. ${ }^{86}$

The religious congregations and the priests of the patriarchate made great efforts to accommodate the refugees. Besides the aid supplied by Belgian bishops, coordinated by a young priest, Léon Naveau, who had earmarked Nazareth for funds, the existing foundations and orders had mobilized before the Israeli occupation. The Franciscans contributed to these initiatives: the custody monastery made various locations available to the foundation created by the Belgian bishops to be used as depots. Further, the Franciscans took care of the sick and of malnourished children, seeking the pro bono assistance of doctors. The Franciscan Third Order prepared a center for aid distribution. The number of refugees "of every rite" in receipt of aid from the Franciscans of Nazareth in those dramatic months "climbed to 6,417".87 Over four hundred refugees from Mujaydil and surrounding villages were housed in the orphanage of the Sisters of Jesus the Adolescent.

Vergani was a key player among the Latin Catholics at that time in Nazareth. Barlassina had transferred the priest there in June 1946, nominating him patriarchal vicar of Galilee. The experience he acquired in Nazareth in the two previous years was of great value in July 1948. When the town went "into torment", abandoned by the Arab troops and surrounded by Israeli battalions, he sought to ensure that his parishioners were guaranteed decent living conditions. ${ }^{88}$ The priest, "always in the breach", ${ }^{89}$ committed himself to helping the foundation of the Belgian humanitarian mission to Nazareth. In the summer of 1948, Vergani also undertook to ensure that by autumn, the Catholic schools would reopen.

86 In the following years, Giacinto Faccio, Custos from 1950 to 1955, described the period of the surrender of Nazareth. See AAV, ADAGP, 17, 68, 2, fols. 22-25, Faccio to Massignon, copy, September 10, 1951, translation from Italian.

87 Ibid.

88 See Pierre Médebielle, "Mgr Antoine Vergani (1905-196o). In Memoriam," Jérusalem: Le Moniteur diocésain du Patriarcat latin 26, nos. 3-4 (1960).

89 Ibid. Translation from French. 
The fall of Nazareth assumed a powerful symbolic significance. The town's importance and value for all of Christianity attracted worldwide Christian attention to the Israeli-Palestinian war, investing the conflict with a level of publicity it had not received in the preceding months. For this reason, Vergani knew that his voice would be heard much more.

A few days after the conquest of Nazareth, Louis Massignon published an article titled "Nazareth et nous, Nazareens, Nasara" (Nazareth and us, Nazarenes, Nasara) in the important French Christian journal Témoignage chrétien, republished in October by the periodical Vie franciscaine. ${ }^{90}$ In this article, the French orientalist presented a heartfelt denunciation of the silence and disinterest which, in his eyes, "Western Christianity" had shown toward the fate of the Holy Places, the Christians in the region and the town of Nazareth. According to Massignon, the European Christian world was in fact to blame for having "betrayed" the Palestinian Christians with respect to the advance of Zionist forces, especially in the city of the Virgin. The centrality assigned to Nazareth served Massignon's chosen rhetoric of bringing together Christianity and Islam in an anti-Jewish and anti-Zionist capacity. Ultimately, he demonstrated the sort of response that news of the conquest of Nazareth could arouse in a European observer, albeit one with very close ties to the Arab world, and what firm ideas and images could be evoked by Tsahal's entry into one of the most important cities of Christianity.

\section{3 "Diabolically Desecrated": Accusations of Profanation}

On the night of July 17,1948 , the Israeli troops also occupied the village of Rafat. Bordering a Jewish colony, it was very close to two more. The patriarchate owned an estate of about 1,200 hectares in the village, which also had two monasteries and a sanctuary dedicated to Our Lady Queen of Palestine, which Barlassina had built in the 1920s. According to Albino Gorla, parish priest of Rafat since 1937, after the beginning of conflict in November 1947, the religious community, comprising three priests and nine nuns, all of them Italians, had opted for "the strictest neutrality" and had not suffered particular harm. ${ }^{91}$ Nonetheless, the situation continued to escalate. Arab forces used the wall surrounding the presbytery as a vantage point to shoot at Israeli convoys, which provoked a violent response from Tsahal. The priests' residence became the target of machine-gun fire and aerial bombardment. On July 13-14, the Israeli

9o The text is contained in Louis Massignon, Opera Minora (Beirut: Dar al Maaref, 1963), 3:490-93.

91 ISA, G/7/5805, Gorla to Ya'akov Herzog of the Israeli Ministry of Religious Affairs, Tisserant and Testa, Dayr Rafat, December 12, 1948, translation from Italian. 
army occupied the neighboring village of Sar'a, where the patriarchate also owned land. The conquest of Sar'a drove the inhabitants of Dayr Rafat into fear as well, with most of them deciding to flee. Fifteen dependents of the patriarchate chose to take refuge in the two monasteries with their families. ${ }^{92}$

On the night of July 17-18, Israeli soldiers entered the two monasteries. In his correspondence, Gorla emphasized their "smiles and comments in the dormitory of the Sisters at the sight of the crucifixes, crowns of thorns, and sacred images". A few days after the occupation of Dayr Rafat, on July 21, the Israeli soldiers assembled the Palestinians who had found refuge in the monastery and took away seven men from among them; "despite all our efforts we could not get any news on these men," Gorla recounted. On the following day, Chaim Wardi, advisor to Ya'akov Herzog in the Israeli Ministry of Religious Affairs, ${ }^{93}$ arrived at Dayr Rafat to announce that the army intended to occupy both the two patriarchal monasteries and the buildings attached to them. The priests objected to this plan and unsuccessfully requested that the military contact Testa, the patriarchal regent, regarding ecclesiastical property. On July 24, "without any warning, numerous vehicles arrived with soldiers and 'soldieresses'; they had come to occupy the two monasteries etc.... The order to evacuate homes within two hours was peremptorily given." ${ }^{24}$ The rest of the Arab population of Rafat and Sar'a had fled in the meantime.

Taking a strong anti-Israeli stance, Vergani circulated some reportshehad prepared among the diplomatic representatives of the principal powers involved in the region, in which he denounced the occupations of religious structures by the Israeli army and protested against some acts of violence - defined as "desecrations" - they had committed. ${ }^{95}$ Vergani's documents, disseminated through the press, evoked a strong response in Europe and the United States,

92 Ibid.

93 Since the 1930s, Wardi (1901-75) had tried to bring about a rapprochement between the Catholic Church and the Zionist leadership. See ushmma, Archive of the Apostolic Delegation in Jerusalem and Palestine, RG-76.oo3, Serafino Mazzolini to Barlassina, alZamalik, January 22, 1934. Yacakov Herzog (1921-72), son of Rabbi Yitshak and head of the Christian communities department at the Ministry of Religious Affairs, oversaw intense efforts to establish early relations between Israel and the Holy See after 1948.

94 ISA, G/7/5805, Gorla to the Israeli Ministry of Religious Affairs, the Oriental Congregation and Testa, Dayr Rafat, December 12, 1948, translation from Italian.

95 See asdmae, Affari Politici (1946-1950), Palestina, 2, typescript report in Italian from Vergani on his visit of July 22, 1948 to the religious institutions in the district of Tiberias, July 27, 1948. Vergani sent another report, dated August 15, 1948, on the situation of the religious communities. This document was widely disseminated by and quoted in the European, Israeli and Arab press. A copy of the text is located in ACO, Latini, Palestina e Transgiordania: affarigenerali, 457/48, 1, doc. 87 . 
receiving particular attention from the US episcopate, which was paying close attention to the events in the region. Cardinal Spellman had received a copy of the letters from Latin and Melkite priests of Jaffa and of texts from the patriarchal vicar of Galilee. The Melkite vicar Gabriel Abu Sada had written to the archbishop of New York appealing for his intervention against the "abominable profanations" conducted by the Israeli army against Catholic structures. ${ }^{96}$ Spellman's response came by way of action from the CNEwA; McMahon sent an appeal to the UN secretary-general, Trygve Lie, requesting that the UN establish an inquiry into "criminal acts against twelve Latin Catholic institutions in the north of Palestine". ${ }^{97}$ McMahon's text to Lie was immediately published by various international newspapers, triggering an Israeli reaction. Eliyahu Ben-Horin, a prominent member of the American Zionist Emergency Council, accused the CNEWA secretary of "atavic antisemitism". 98

From Haifa, Fr. Pierpaolo Podagrosi, writing to the Custos, denounced the damage inflicted by Israeli soldiers on the Franciscan hospice: "all that is most sacred to the hearts of Christians was diabolically desecrated."99 There were also protests at the army's actions from Dayr Rafat. A series of letters addressed to the Ministry of Religious Affairs denounced the behavior of the Israeli soldiers toward the patriarchate's monastery. Once again, Gorla was behind these denunciations. ${ }^{100}$ On September 14, 56 days after the village's occupation, the village itself was blown up, while the convents were evacuated in November and the priests forced to leave.

\subsection{On the Frontline: the Conflict Around Notre-Dame de France}

Following the first truce, Jerusalem remained a key theatre in the fighting between the Israeli army and Arab troops. After the Jewish Quarter of the Old City surrendered to the Arab Legion on May 28, the city was split in two: west Jerusalem, on one side, was in Israeli hands, while the eastern part and the

96 AANY, ACNEWA, Abu Sacda to Spellman, Jerusalem, August 16, 1948.

97 AAnY, ACNEwA, McMahon to Trygve Lie, New York, August 20, 1948. Here, McMahon quoted Vergani, who spoke of the monasteries and parishes "in the north of Palestine": the more-or-less conscious refusal to use the term "State of Israel" in these documents and in much of the correspondence of the patriarchal clergy after 1948 is noticeable here, also because of the absence of recognition by the new state on the part of the Vatican.

98 The comments were reported in AANY, ACNEWA, memorandum for Cardinal Spellman from McMahon, New York, August 24, 1948.

99 ASCTS, Acc, Miscellanea, Guerra arabo-israeliana, Rapporti di religiosi (August 12, 1948January 22, 1949), Podagrosi to Gori, Haifa, August 29, 1948, translation from Italian.

100 See Maria Chiara Rioli, "The 'New Nazis' or the 'People of our God'? Jews and Zionism in the Latin Church of Jerusalem, 1948-1962," Journal of Ecclesiastical History 68, no. 1 (2018): 9o-91. 


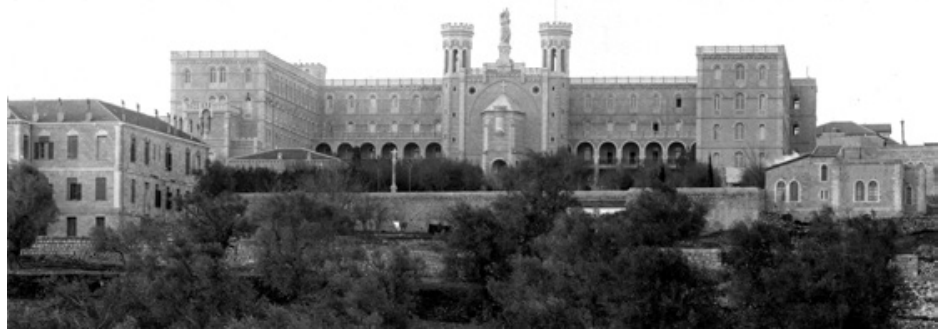

FIGURE 2.4 Notre-Dame de France, late nineteenth-early twentieth century

AAAJ/AEBAF

area within the walls was under Arab control. ${ }^{101}$ The battle to take positions on the border between the two zones lasted several months. Some religious buildings were at the center of the struggle, putting their religious inhabitants in the crossfire of the two sides. One of the most important of these positions was certainly the Assumptionists complex of Notre-Dame de France, north of the New Gate (fig. 2.4).

Since its foundation at the end of the nineteenth century as part of France's diplomatic ambitions in Jerusalem, Notre-Dame de France had been one of the principal places to receive pilgrims to the Holy City for decades, and thus represented a privileged observatory for the sociopolitical transformations in Palestine. ${ }^{102}$ Between the nineteenth and twentieth centuries, the Assumptionist community had pondered the sequence of events and attested to the fears of part of the European Catholic population in Jerusalem, faced, first, with the prolonged decline of the Ottoman Empire and, later, with the institution of the Mandate, and finally the escalating conflict between Arabs and Jews. In the course of the war of 1948, its position on the border between the Arab and Jewish sectors, a no man's land delineated in November of that year, put the Notre-Dame de France complex at the center of the fighting for the conquest of the city. The war split the community of Assumptionists in Jerusalem in two. Notre-Dame de France and St. Louis hospital fell within the

101 For a historical reconstruction of the events and transformations undergone by Jerusalem in the course of the Palestine War, see Tamari, Jerusalem 1948.

102 See Dominique Trimbur, "Une présence française en Palestine: Notre-Dame de France," Bulletin du Centre de recherche français à Jérusalem, no. 3 (1998). 


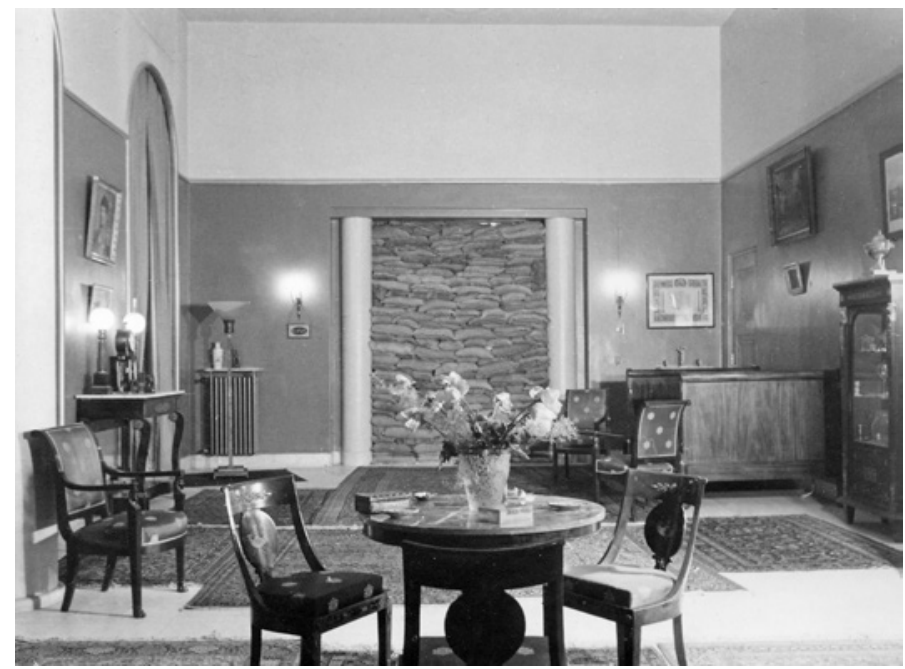

FIGURE 2.5 Salon of the French Consulate in Jerusalem, 1948 APRN/AEBAF

new state, while the clergy of St. Peter in Gallicantu were in the territory controlled by the Arab Legion.

Notre-Dame de France witnessed the drama of the conflict at close quarters. One of the priests, Pascal Saint-Jean - who would become the community's superior in 1948 - reported on the course of events with precision, evoking a clear picture of the fighting within the city and of the state of mind of the clergy confined within it. The French complex had already experienced military occupation in 1939, when, at the outbreak of the Second World War, British troops seized it. News of the abandonment of the Assumptionist building by the British army on the night of May 13-14 was received with surprise by Saint-Jean, who saw it as an unexpected and hasty departure. Faced with this situation of great uncertainty, the priest met with the French consul, Réné Neuville, who was trying to prevent attacks on the Jerusalem consulate (fig. 2.5). With Saint-Jean, the consul determined that, in order to safeguard the building, two flags should be hoisted, on the house of the Franciscan priests and on the neighboring St. Louis hospital: a French one and a Red Cross one. Saint-Jean's conviction that relations between Arabs and Jews were about to deteriorate would be confirmed. On the same day, a group of irregular Arab combatants burst into the area around the hospital. ${ }^{103}$ The occupation was

103 The attempt by the Assumptionist priest to oppose their entry, "making a rampart out of my chest against them repeatedly," was unsuccessful. AAAJ, Rapports avec les autorités militaires, 4, Correspondance avec les autorités militaires israéliennes, 1947-1948, account 
followed by the sacking of the building by the Arab militia and the first violent exchanges of fire with nearby enemy troops on May 14-15.

On the next morning, Saint-Jean was summoned to the French hospital, where some Israeli officials informed him that they would shortly try to occupy Notre-Dame de France. A few hours later, about fifteen soldiers stormed the Assumptionist house, breaking doors and windows. Inside the building, a firefight broke out between the Arabs, shielded by their positions, and the enemy troops. The fighting lasted for four days. In the middle of the night on May 19, the clergy were awakened by another round of fighting, followed by the Israelis' occupation of the Assumptionist complex. Nine Arab soldiers died in the course of the assault. The southeast wing of the hospital in front of the New Gate was blown up, while the Israeli troops transported sandbags to create redoubts within the building (figs. 2.6-2.7).

The incessant fighting that followed prevented the clergy from leaving their rooms for several days. Saint-Jean was struck in the eye by a piece of shrapnel and, on May 2o, Fr. Mamert Vionnet, the community superior, was killed in his study after he was hit by a projectile. His body was buried in a trench in the

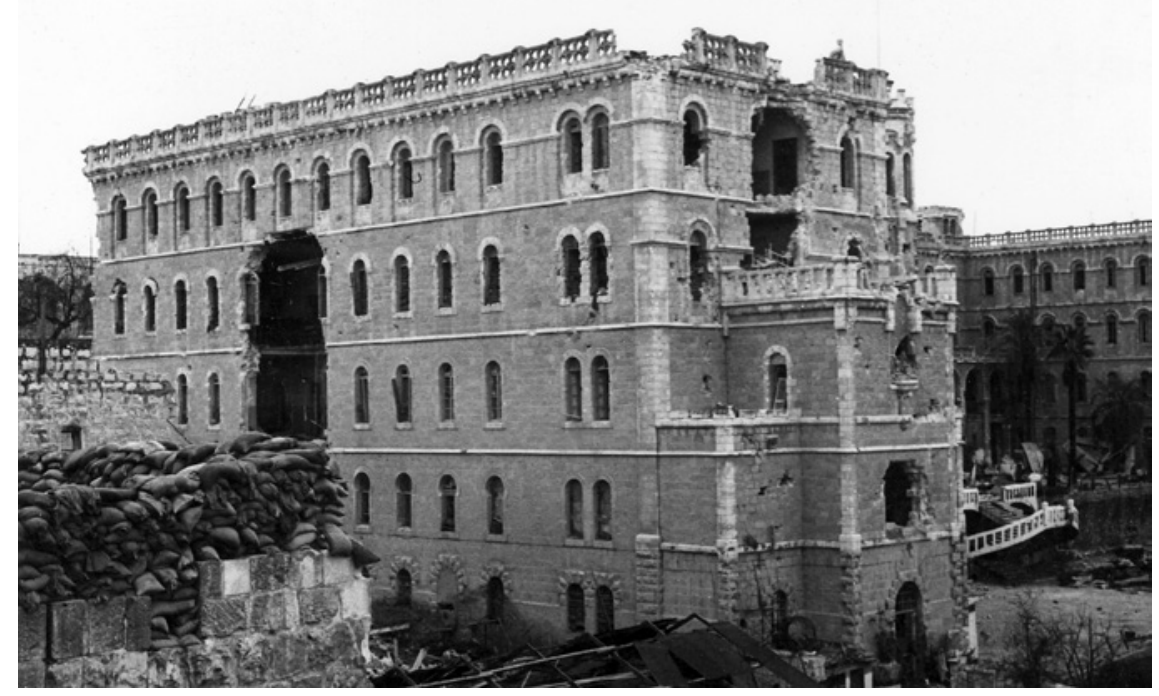

FIGURE 2.6 Notre-Dame de France, 1948-49

APRN/AEBAF

by Fr. Saint-Jean to the Israeli authorities of Jerusalem, titled "Occupation et siège de l'Hôtellerie de Notre-Dame de France en Mai et Juin 1948," Jerusalem, June 11, 1948. 


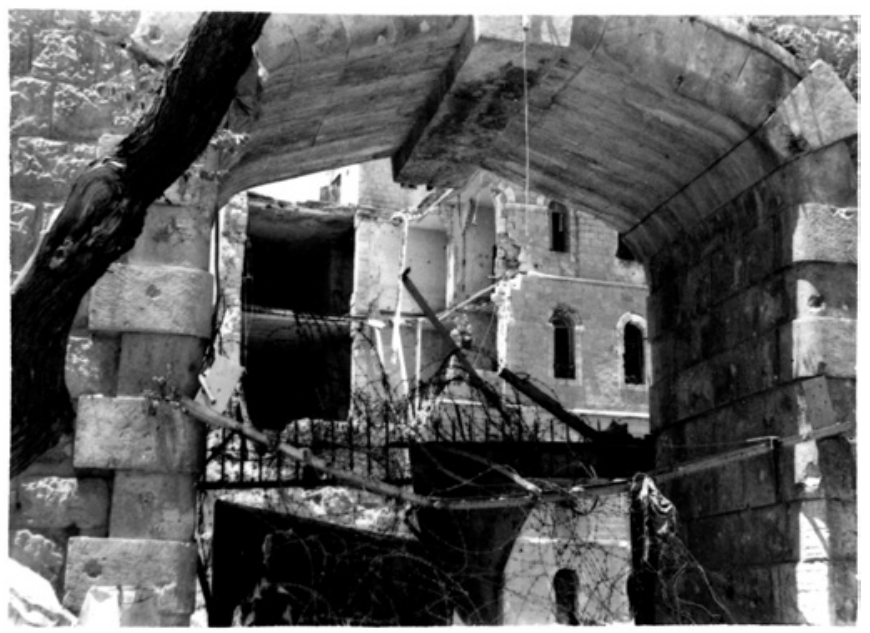

FIGURE 2.7 New Gate, barbed-wire fence in no man's land with Notre-Dame de France to the rear, 1948 ASFMMJ/AEBAF

hospital garden, together with the nine Arab soldiers killed on the previous day. The desperate conditions of living under continuous fire from machine guns and artillery forced the clergy to move to the French hospital to avoid further danger.

During those weeks, the Assumptionist community also hosted the Anglican archdeacon of Palestine, Syria and Transjordan (and later archbishop of Jerusalem), Campbell MacInnes, who was wounded during the fighting in Jerusalem. He and his wife went to St. Louis hospital, where he was operated on. Observing through the windows of the French complex, his terrified wife compiled an account that sheds further light on the course of events and how they were perceived by direct observers. ${ }^{104}$

At the end of May, the Israelis struck the convent of the Sisters of Mary Reparatrix, destroying most of it, with the aim of preventing the Arab army from using it as a defense post (fig. 2.8). On the night of May 26-27, MacInnes's wife was awoken by the reflection of flames coming from the convent; the Israelis also took over the French hospital, placing sentinels on it with rifles and machine guns. On June 11 came the announcement of a truce, with few

104 TNA, FO 371/68511, E 8525, copy, sent by Eric Mills to David Balfour, from the diary kept by Mrs. MacInnes in St. Louis hospital during the fighting, 12 typescript pages, strictly confidential, Jerusalem, May 17-June 16, 1948. 


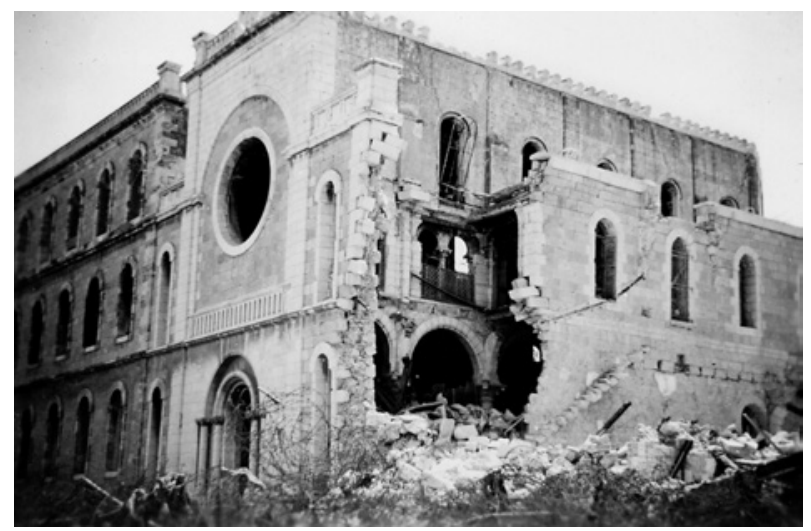

FIGURE 2.8 Reparatrix Convent near Notre-Dame de France, 1948

APRN/AEBAF

observers expecting the peace to last. Saint-Jean displayed a realist streak in the face of the ceasefire, asking, "for how long?"105

In the months that followed, aside from the damage to the entire complex, the Assumptionists were most upset about the desecration of the chapels within the premises. The attacks galvanized hostile sentiments, focusing it even more intently on the Israeli army. The tone and arguments were similar to those used by the patriarchal clergy who had witnessed desecrations in Galilee. As the war drew to a conclusion, Saint-Jean, who wrote that they had "transformed a house of prayer into a W.C.", summed up the impression of the Catholic population of Jerusalem of Tsahal troops. ${ }^{106}$

\subsection{Women Within the Walls: the Sisters of Notre-Dame de Sion in the Ecce Homo and Ayn Karim Convents}

The female religious within the Old City also mobilized in the face of the events taking place in Jerusalem. Among the best-known of these were the Sisters of Notre-Dame de Sion, founded in the mid-eighteenth century in Paris by brothers - and Jewish converts - Théodore and Marie-Alphonse Ratisbonne. They created a religious community composed of female and

105 AAAJ, Rapports avec les autorités militaires, 4, Correspondance avec les autorités militaires israéliennes 1947-1948, report in French by Fr. Pascal Saint-Jean to the Israeli authorities of Jerusalem, titled "Occupation et siège de l'Hôtellerie de Notre-Dame de France en Mai et Juin 1948," Jerusalem, June 11, 1948.

106 AAAJ, ibid., Fr. Saint-Jean to Bernard Joseph (later Dov Yosef), military governor of Jerusalem, copy, Jerusalem, December 13, 1948, translation from French. 
male branches, with the specific goal of being an apostolate for the conversion of Jews to Catholicism. Marie-Alphonse Ratisbonne himself went to Palestine to establish a branch of his congregation to serve as an apostolate for the Jews of the region. In $185^{8}$ he opened the convent for the Sisters of Notre-Dame de Sion on the ruins of the Ecce Homo Arch, on the Via Dolorosa near al-Asbat Gate, in the Muslim Quarter in the Old City. The Ecce Homo Arch is one of the most important symbolic sites in the Christian tradition, which identified it as the site of Jesus's condemnation to death. In 1862, a school and an orphanage for girls were also opened in the convent, which became one of the city's most important educational institutions. In those years, another convent was founded on the hills of 'Ayn Karim (fig. 2.9). In Jerusalem the Fathers of Sion also built St. Peter's Monastery in the Rehavyah neighborhood (fig. 2.10).107

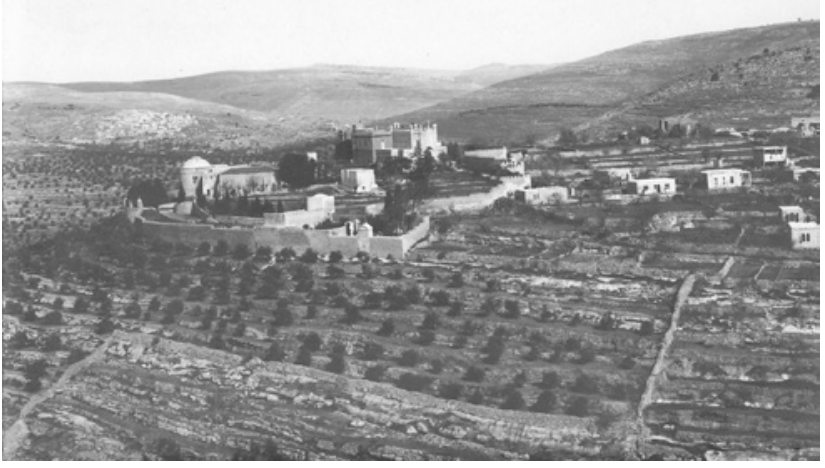

FIGURE 2.9 'Ayn Karim, ca. 1927

ASNDS

107 On the history of the congregation in Palestine, see Karène Sanchez Summerer, "La réception et les impacts de l'action éducative et sanitaire des sœurs de Saint-Joseph et des sœurs de Sion par les populations musulmanes rurales et urbaines en Palestine ottomane et mandataire (1870-1940)," Histoire et Missions chrétiennes, no. 22 (2012); Sanchez Summerer, “'Ouvrir les trésors de la charité aux enfants dévoyés d'Abraham': L'action éducative des sœurs de Sion en Palestine ottomane et mandataire (186o-1948)," in L'enseignement français en Méditerranée: Les missionnaires et l'Alliance israélite universelle, ed. Jérôme Bocquet (Rennes: Presses universitaires de Rennes, 2010); Mona Hajjar Halaby, "School Days in Mandate Jerusalem at Dames de Sion," Jerusalem Quarterly, no. 31 (2007): 40-71; Olivier Rota, "Notre-Dame de Sion en Terre sainte: Évolutions parallèles des maisons de l'Ecce Homo et d'Eïn Karem. Vers des lieux de rencontre et de dialogue (1948-1967)," Tsafon, no. 47 (2004). 


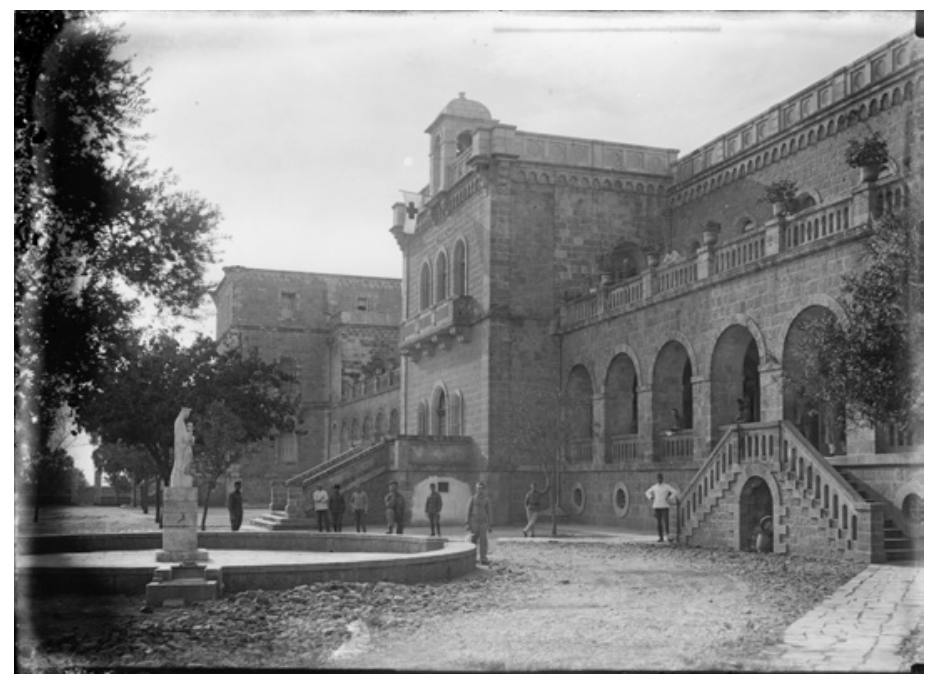

FIGURE 2.10 Ratisbonne Monastery, 1916

MPC

During the Mandate, most of the pupils of the Ecce Homo school were Palestinian Arabs, while the sisters mostly came from Europe, France in particular. The school also enrolled Jewish girls ready to receive the Christian sacraments. In the early 1940s, meanwhile, the school of the Fathers of Sion was attended by about three hundred pupils, most of them of Jewish origin, thanks to the activism and philosemitism of Fr. Pierre de Condé. The sisters also opened a high school, attended by British girls, in the Katamon Quarter. The community's archives, housed in the 'Ayn Karim convent, are a rich documentary source for the educational, social and religious life of the community and its relations with the surrounding territory and institutions. One of the most interesting sources is the journal of the Ecce Homo convent, which notes the daily events and opinions of the nuns, of their pupils and religious family throughout Palestine (fig. 2.11).

The chronicles of 1947 reflect the anxieties and uncertainties of a female religious community in the face of political upheaval. They viewed the King David Hotel bombing as "a catastrophe". ${ }^{108}$ The victims included some of

108 "A terrible test was enjoined today upon the Holy City and threw us into consternation! At 12:30 p.m., a bomb set by the Jews blew up part of the King David, where the English offices are located and where an important meeting of the principal government functionaries was to be held. A great number of victims are already known about, but many are still buried under the rubble. The dead include Mr. Gres, a father of four children that we had at the boarding school; two are still there - children who have already lost their 


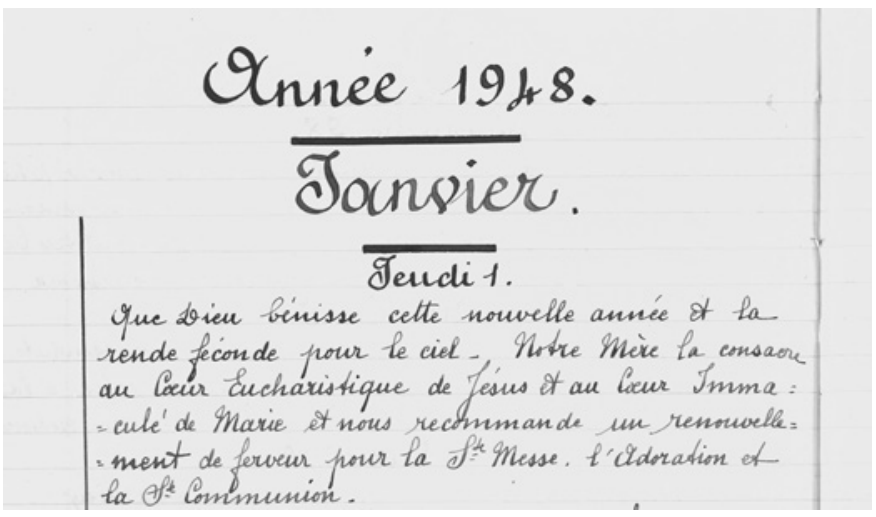

FIGURE 2.11 Ecce Homo journal, 1948

ASNDS

the city's important political figures, in particular 'Atallah Mantoura, assistant district commissioner and a friend of the community. The sisters note that "the political situation ... is becoming more and more unsettling here; the bombs, the assassinations are multiplying". ${ }^{109}$

The order to repatriate women and children who were British subjects emptied the Katamon school. On the eve of battle, only about twenty pupils remained. The Palestinian children were also returned to their parents' villages. As barbed wire and checkpoints sprung up in Jerusalem, the sisters became increasingly convinced that the city would soon be under siege. Amid this uncertainty, the chronicles describe the ordinary activities that continued despite the political situation: the lessons and exams, the games and entertainments prepared by the boarding girls (called "les bleuettes" on account of their uniform) for the children of the orphanage, the life of prayer, the community gatherings and meetings with other clergy.

In June 1947, the announcement of a strike by the AHC against the UNSCOP's works also affected the Sisters of Sion. As reported by the community's chronicle, the committee sent a letter to the superior demanding the suspension of lessons. On November 29, the nuns viewed the UN resolution to partition Palestine as "all to the advantage of the Jews". ${ }^{110}$ The agitation in the city

mother three years ago. Mr. Mantoura is among the missing - many other families known to us have also been touched by this catastrophe" (July 22, 1946). ASNDS, Ecce Homo, Journal de la communauté (July 1, 1946-December 31, 1947), translation from French.

109 Ibid., December 2, 1946.

110 "They are indulging in excessive rejoicing all day long: the unhappy Arabs are preparing for a three-day strike" Ibid., November 30, 1947. 
induced the educational institutions to close for a week. The nuns, in contact with the French consul, Neuville, continued to accept girls; the chronicle notes anxious telephone calls from parents and their gratitude to the nuns for their assurances that they would keep their daughters. A few days later, the announcement of the British withdrawal from Palestine led the nuns to decide that the students from Jaffa, Tel Aviv and Haifa should leave, so that they could travel while the roads were still controlled by the military. Meanwhile, communications between the nuns in Jerusalem and the sisters in 'Ayn Karim were also becoming ever more difficult.

The following year opened with new bereavements: the names of former pupils who had died in the bombings fill the pages of the chronicle. The escalation of conflict also necessitated some modifications to the school timetables and the organization of the community space. The timetables were made shorter to enable day pupils to return home, avoiding the most dangerous quarters. Borders were gathered in two rooms.

During the fighting, the nuns repeatedly complained to the Yishuv authorities: the mother superior presented herself several times at the offices of the Jewish Agency to denounce the damage by Haganah on the convent's high school. These meetings allowed for "some good clarifications regarding the Arabs' sentiments toward them [the Jews], in response to their odious conduct of recent weeks."111 Meanwhile, the nuns characterized the AHC's behavior as "perfectly correct".112

Liturgical life continued, but here too the conflict necessitated changes. Some of the Easter ceremonies of 1948 were canceled, among them the traditional Palm Sunday procession at Bethphage, while some liturgies were placed under the escort of Arab troops (fig. 2.12).

It was the arrival of the first individuals and families requesting the nuns' aid that really transformed their daily life. Spaces once reserved solely for the nuns were now also populated by men: not only were clergy forced to stay for a few nights because the streets were impassable, but refugees too as the battle continued to focus increasingly on Jerusalem. School classes, already attended by very few pupils, were adapted to accommodate the displaced. The term "refugee ladies" (dames réfugiées) appears for the first time in the entry for April 25, 1948, but already in January there was reference to families being hosted at the Franciscan Monastery of the Flagellation. Meanwhile, a portion of the convent's lay staff left their jobs and Palestine altogether.

111 ASNDS, Ecce Homo, Journal de la communauté (December 1-31, 1948), January 18, 1948.

112 Ibid., February 25, 1948. 


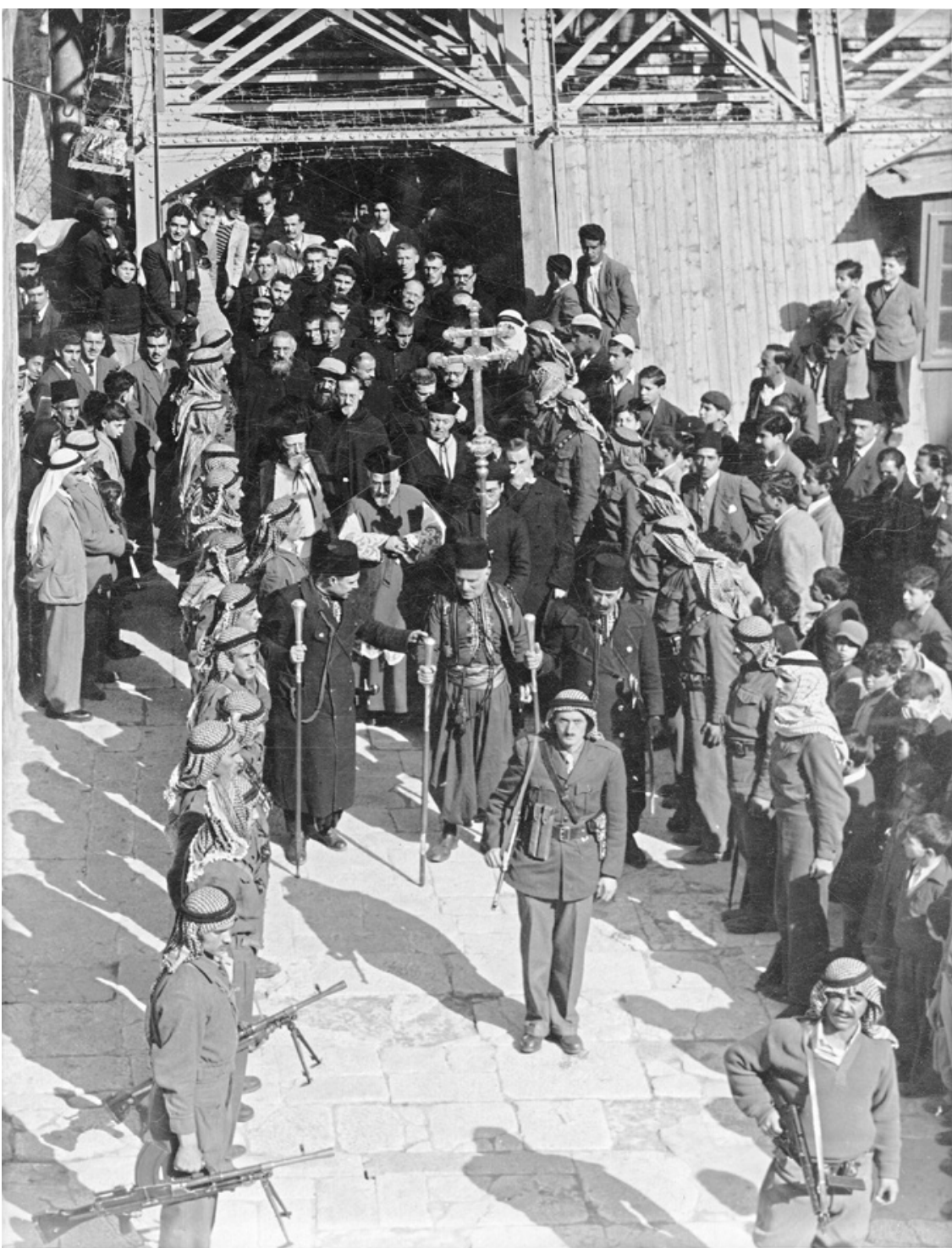

FIGURE 2.12 Patriarch Barlassina leaves the Church of the Holy Sepulcher, escorted by Arab Liberation Army leader 'Abd al-Qadr al-Husayni, 1948 APLJ/AEBAF

The sisters in the Ecce Homo convent followed the fighting around 'Ayn Karim, concerned for the fate of their sisters and expressing explicit support for the Arab forces. ${ }^{113}$ Their admiration for the Palestinian commanders is clear,

113 "A great battle at al-Qastal in the neighborhood of St. John; first taken by the Jews, this village was then recaptured by the Arabs. Great shows of enthusiasm in the afternoon in 
as in the case of 'Abd al-Qadr al-Husayni, the Arab Liberation Army leader, who fell in the battle of al-Qastal, where, according to the chronicle, he had fought "bravely and heroically". On the opposite side, Haganah was blamed for "atrocities against women and children".114 The 'Ayn Karim convent chronicle portrays al-Qadr al-Husayni ${ }^{115}$ and the Zionist attack on Dayr Yasin ${ }^{116}$ in a similar light. While the Ayn Karim nuns hosted up to three hundred refugees, some of whom had brought their furniture with them to save it, ${ }^{117}$ news arrived of the Jewish capture of Haifa. "The Jews ... have begun the same massacres that they have performed in the villages," the Ecce Homo chronicle commented. ${ }^{118}$

The mounting pressure on Jerusalem is also increasingly evident in the nuns' community diary. The Haganah occupation of the Sisters of Sion high school fueled their anti-Jewish resentment. ${ }^{119}$ In mid-May, the departure of the British nuns ordered by the Mandate government, the request for hospitality from refugees from Dayr Yasin, the expectation of the arrival of the Transjordanian army, and the fears of a new world war gave rise to great anxiety. ${ }^{120}$ The nuns at the Ecce Homo convent maintained close contact with the Arab Committee and hosted some prisoners of war at the latter's request. About thirty beds were assigned to the wounded. In June, the convent hosted the office for the exchange of prisoners of war. ${ }^{121}$

this quarter, the staff of the Arab army being established in front of us, in the old Muslim school." Ibid., April 8, 1948.

114 Ibid., April 9, 1948.

115 The Palestinian commander, nephew of the mufti, was described as a "valiant chief", whose death was judged in the chronicle as a "very great loss". ASNDs, Ayn Karim, Journal de la communauté 1948, April 8, 1948.

116 "In Dayr Yasin, a small village that we see from our class windows, the Jews attack and commit atrocities against the women, children, kill the men, they throw them in a tank, they cut the children's hands, they undress the women and they lead them to Tel Aviv." Ibid., April 9, 1948.

117 "In the afternoon we are invaded by women and children, bringing mattresses, pillows, covers for the night. Around 300 came. They are scared, the Jews come to al-Qastal. We gave them the big rooms in the old house. It filled quickly." Ibid., April 1, 1948.

118 ASNDS, Ecce Homo, Journal de la communauté (December 1-31, 1948), April 23, 1948.

119 "Dawd comes at midday to warn Our Mother that the Jews forced open the doors to the high schools, took up positions, and were in the process of dancing with us, to the accompaniment of the radio!" Ibid., May 3, 1948.

120 "Several persons have still asked us to receive them ... Mlle Hind al-Husayni here, on the instructions of the committee that deals with the orphans of Dayr Yasin, the village taken by the Jews last month, asks us if we could receive 45 of those poor children; the quarter in which they had been installed being under heavy bombardment, one cannot let them stay there. Our Mother responds affirmatively." Ibid., May 14, 1948.

121 "In the evening, Our Mother received 'Abd al-Qadr al-Husayni, general of the Arab Liberation Army, accompanied by the Rev. Fr. Ibrahim 'Ayyad of the Latin Patriarchate, as well as one of the heads of the Arab League, who came to ask for hospitality for a Jewish female. The Jews having taken an Arab family hostage, the Arabs in turn took a Jewish 
In July Tsahal took over some villages southwest of Jerusalem, displacing and expelling three more populated villages in that area, 'Ayn Karim, al-Malha and Lifta. ${ }^{122}$ The battle, which started after the end of the truce, lasted some days. In the 'Ayn Karim chronicles, the Sisters of Sion wrote that "the Jews will enter St. John's tonight, or maybe tomorrow? Is it true? Anyway, it's time to ... submit to God's will." 123 On July 18 , the army entered the convent, stating they were occupying the village. A group of 35 soldiers billeted in a room for some days: "They are all very correct, very polite, telling us do not be afraid, we will look after you better than the Arabs." ${ }^{124}$ This positive judgement on the army's behavior, ${ }^{125}$ as well on the Israeli police officers and the engineers and architects of the antiquities department that visited the village, ${ }^{126}$ contrasts with the tone of the chronicles of the nuns in the Transjordanian side of Jerusalem.

Indeed, the Ecce Homo journal for the summer of 1948 highlights the increasing fears that the Israeli troops would prevail, which would bring "the triumph of communism and irreligion", to which they added the prayer "that God ... grant victory" to the Arab side. ${ }^{127}$ As news arrived of the Israeli army's expulsion of the civilian populations of Lydda and al-Ramla, ${ }^{128}$ the Ecce Homo community viewed the truce and the peace proposals with skepticism.

At the end of the summer, the nuns reopened their schools and boarding schools, although few students reported for the beginning of class. Meanwhile the nuns agreed to the request to host 'Abdullah al-Tall, the Arab Legion colonel responsible for Jerusalem during the war. In the autumn, some refugees vacated the rooms provided to them by the convent as the violence flared up again in the autumn, with no end in sight.

family so as to be able to make an exchange. This Jewish family included a young girl, and the Arabs did not deem it appropriate to make her spend the night in camp; thus they asked Our Mother to be willing to take her in for the night while waiting for the formalities with the Red Cross of Geneva to be concluded. Our Mother willingly agreed to what was asked and took this young girl in." Ibid., April 6, 1948.

122 See Salim Tamari, "The City and its Rural Hinterland," in Tamari, Jerusalem 1948, 71-74.

123 ASNDS, 'Ayn Karim, Journal de la communauté 1948, July 13, 1948.

124 Ibid., July 18, 1948.

125 "They don't stop thanking us, they make us visit the room so that we can see that they leave everything in order." Ibid., July 20, 1948.

126 "An engineer with his map ... says: 'We don't want the war, but to create a country flowing with milk and honey, like at the times of Moises, and of Jesus Christ." Ibid., July 26, 1948.

127 ASNDs, Ecce Homo, Journal de la communauté (December 1-31, 1948), July 8, 1948.

128 "The Jews, despite the truce, have seized the neighboring villages, Lydda and al-Ramla, from whence they have expelled all the inhabitants, who are wandering on the roads." Ibid., August 3, 1948. 

the War

\subsection{The Final Wave of Refugees}

On September 16, Count Bernadotte submitted his second report to the UN secretary-general. Both parties rejected Bernadotte's proposal. The next day, the Stern Gang assassinated him in Jerusalem. ${ }^{129}$ After the UN mediator's killing, the possibility of maintaining the second armistice seemed increasingly weak. The situation deteriorated on October 15 following a new clash between Egyptian and Israeli troops in the south. In the following weeks, the Israeli army managed to occupy several strategic positions, thus considerably increasing the territory under its control. During Operation Yo'av, the most important regions conquered by the Israeli troops were the southern coastal strip, the city of Beersheba, the area around Hebron, including Bayt Jibrin, and some of the villages to the south of the road between Tel Aviv and Jerusalem. The mass of Palestinian inhabitants who were expelled or fled their homes headed south, especially toward the Gaza Strip, but also in and around Hebron and Bethlehem.

Apart from the south, battles raged elsewhere; Galilee became the center of conflict once again, under Operation Hiram. In late October, Tsahal faced off the troops of the Arab Liberation Army and a Syrian contingent. The result was a heavy defeat for the Arab side, followed by the Israeli occupation of numerous villages and a new - fourth - wave of expulsions. Some of the conquered villages were inhabited by Muslims and Christians, and others had a large Christian, predominantly Melkite, majority, such as al-Jishsh, 'Aylabun, al-Rama, Iqrit, and Kafr Bir'im. The occupation of these villages was not without bloodshed, and Christian civilians were among the fatalities. Some tens of thousands of people sought refuge in Lebanon. Others, mostly Druze and Christians, remained in their homes. Operation Hiram also involved Israeli incursions into southern Lebanon, with the specific goal of impeding the return of Palestinian refugees to their former villages.

At al-Rama, a village on the Lebanese border, an Italian priest, Michele Demaria, found himself entrusted with the care of the Melkite population after the Greek Catholic curate fled to Lebanon with other refugees. The Sisters of the Rosary were also present in the parish, which had a hundred congregants in 1946; they operated a school which had about a hundred students on the eve of the conflict. The capture of the village, in October 1948, was accompanied by raids on the homes of Latin parishioners and others. Witnesses spoke of

129 See Shlaim, The Iron Wall, 39. 
mass graves. ${ }^{130}$ Vergani and McMahon had visited the area about two months before the fighting, bringing money and aid. ${ }^{131}$ There were also some refugees from Iqrit in the village, most of them Melkites. The parish of al-Rama swelled with the arrival of refugees from the surrounding area; by 1950, there were 147 parishioners.

As Vergani himself related to McMahon on his journey to the north of Israel, the village that had struck him the most was Aylabun. ${ }^{132}$ Mostly inhabited by Christians, it was occupied on October 30, while the inhabitants took refuge in the church. Fearing violence and expulsions, they hoisted a white flag. Twelve youths were killed, and the approximately eight hundred inhabitants were forced to march toward the Lebanese border. Some managed to escape. Just five old people remained in the village.

Impelled by the terrible news from 'Aylabun, Vergani sought permission from the Israeli authorities to visit the village, receiving a permit one month after the attack. Upon arrival, he found the old people who had stayed in the village wandering the streets, suffering from hunger. The houses had been sacked. The patriarchal vicar now pledged to intercede with the Israeli authorities to allow the inhabitants to return, and obtained permission for 150 of them. Vergani described to McMahon the scene of desolation that he encountered in 'Aylabun; the latter, in turn, reported this to Cardinal Spellman. The story of this village spread rapidly abroad, especially among US Catholics. A few months later, in January 1949, McMahon met refugees from the village in Tyre.

In this phase, too, it is not clear whether the Israeli army was given orders to treat the different religious components differently, particularly Muslims, Christians and Druze. If the Druze leaders were substantially aligned with Israel's military and political designs and had negotiated a nonbelligerence agreement that enabled the Druze population to avoid the expulsions and remain in their homes, it is more difficult to reconstruct the relationship between the Israeli command and Christian church representatives with respect to the fate of coreligionists in the villages. With Hakim, the Melkite component had a capable negotiator with Israel since the outbreak of the 1948 conflict; the Greek Catholic bishop succeeded in avoiding the expulsion of his

130 This information reached the international Catholic press, as evidenced in a letter from Frank A. Hall, director of the National Catholic Welfare Council (NCWC) news service, to Moses Jung, of the American Jewish Committee. ISA, G/14/5826, Washington, May 25, 1949, copy. On the events in al-Rama, see Morris, Birth of the Palestinian Refugee Problem, $476-77$.

131 AANY, ACNEWA, McMahon to Spellman, copy, December 12, 1948.

132 ISA, G/14/5826, Hall to Jung, Washington, May 25, 1949, copy. Concerning 'Aylabun, see also Morris, Birth of the Palestinian Refugee Problem, 479-8o. 
congregants in a few cases, but more frequently he had engaged in intense mediation aimed at ensuring that the refugees would be allowed to return to their homes at the end of the war. The Latin situation was different. Without a patriarch, and with the regent, Testa, far away from Jerusalem and even farther from Nazareth, it was impossible to attempt any real mediation between the Catholic hierarchy and Israel. Vergani was the sole point of reference, but he had neither the legitimacy nor the concrete opportunity to develop a real political diplomatic strategy and, in this phase, he had decided to devote his full attention to offering concrete assistance to the refugees. And, thus, in general the Latin Catholics shared the fate of the Muslims (who were considered the main enemy of the Jewish world), and were transferred and forcibly expelled, unless they fled first from the Israeli occupiers. For the Latin Catholics, the time for political negotiation would come a few months later, with the end of the fighting and the appointment of a new patriarch. Israel was, however, aware that the expulsion of the Catholics risked reinforcing the opposition of the Holy See and augmenting the Vatican's arguments in the UN discussions. In any case, Vergani once again affirmed that he was on the verge of collapse, exhausted by the "continuous activity demanded by the terrible conditions right now." The priests and nuns, who were "often the only survivors" in contexts where the population had been expelled or had taken to flight because of the fighting and violence, continuously appealed to the vicar general for aid "and, most of all, moral support".133

In Jerusalem, the Catholic institutions were assessing the damage (figs. 2.132.14). The Roman Catholic leaders complained that here was "an overall plan [to] gradually to replace Christian institutions", evidenced by the conversion of the schools of various congregations into offices, hospitals and Israeli military command posts. ${ }^{134}$ At the end of 1948, Palestinian Latin Catholics, too, were in the grip of uncertainty. ${ }^{135}$

133 APLJ, AG, Vicariat Nazareth, 1948-1961, Mons. S.E. Kaldany, Vergani to Girard, Nazareth, October 22, 1948, translation from Italian.

134 "The Christian, not without reason then, lives in a state of anxiety, not to say fear, while he awaits the outcome of the Palestine Problem, and the Problem of Jerusalem." Ascts, Acc, Miscellanea, Guerra arabo-israeliana, Rapporti di religiosi (August 12, 1948-January 22, 1949), transcript of a declaration by Fr. Patrick J. Coyle and Fr. Theophane Carroll, Terra Sancta College, Jerusalem, September 30, 1948). Like the reports of Vergani, this communication by the two Franciscans was the subject of considerable international attention and dissemination.

135 For a study of the history and anthropology of Arab and Jewish memories of 1948, see Efrat Ben-Ze'ev, Remembering Palestine in 1948: Beyond National Narratives (Cambridge: Cambridge University Press, 2011). 


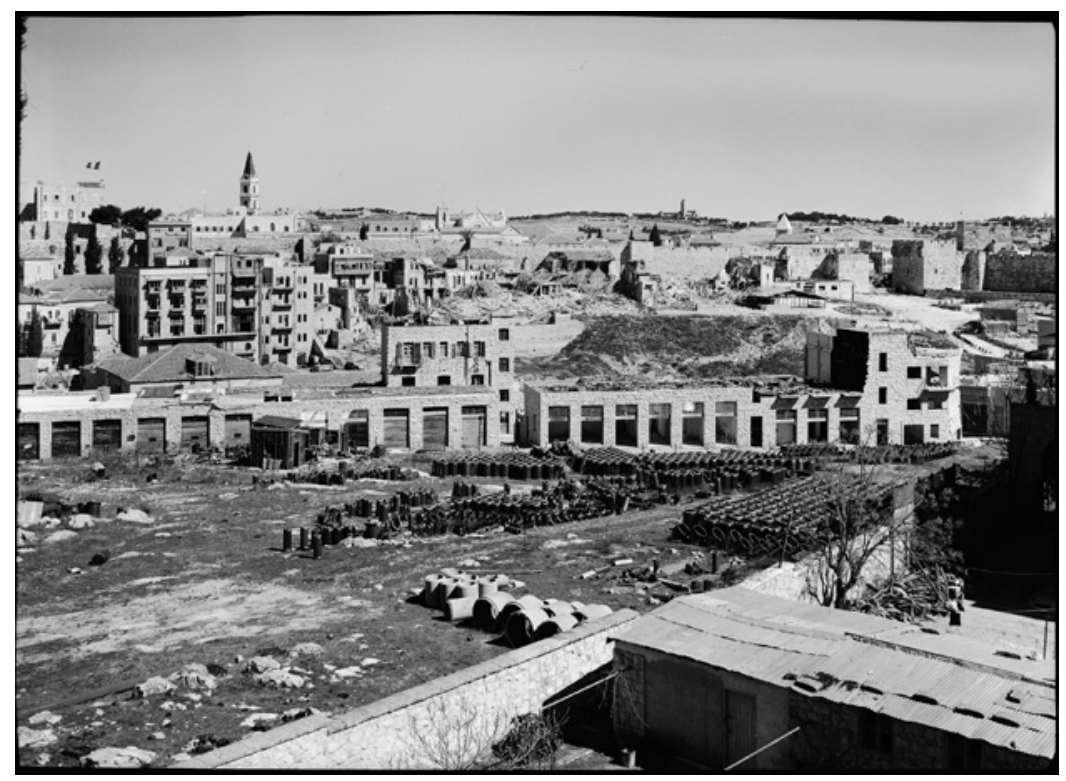

FIGURE 2.13 View from the Pontifical Biblical Institute: on the top left the Lasallian College, St Saviour's Monastery and the seat of the Latin Patriarchate, 1948-49

APIB/AEBAF

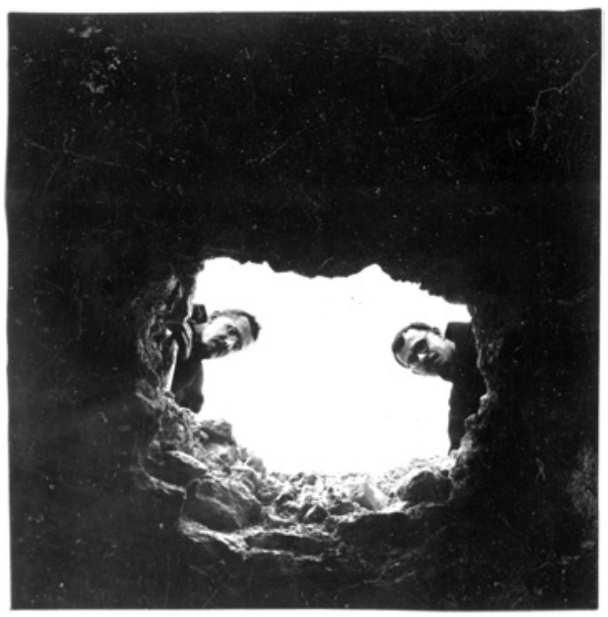

FIGURE 2.14

Aftermath of the bombing near the Franciscan St. Saviour's Monastery, September 12, 1948

APLJ/AEBAF 


\subsection{Armistices, Not Peace}

In the final phase of the conflict, Tsahal committed itself to creating conditions that would impede the return of refugees and Arab "infiltrators", as they were defined in Israeli military documents. The expulsion of the villages on the northern border of the State of Israel was complete. Next came the requisition of the property of the Arabs who had fled or left of their own accord. At the same time, the Israeli forces made efforts to seek out and expel not only the inhabitants of the zone bordering Lebanon and Syria, but also anyone who had attempted to return to their homes in Galilee. The same process went on in the south of the country. Here too, the Israeli army was committed to expelling most of the Arabs. At the end of December, the Israeli army launched Operation Horev, aiming at a decisive victory over the Egyptian troops.

In January, after a series of defeats, Egypt sought an end to the hostilities. The ceasefire came on January 7,1949 , by which time Israel had completed the conquest of the Negev. Egypt, however, remained in control of the Gaza Strip. Just a week later, on January 13, the Israelis and Egyptians discussed the terms of the armistice on Rhodes, where the negotiations were mediated by Ralph Bunche, appointed UN chief mediator after Bernadotte's assassination. ${ }^{136}$ Separately, these negotiations also included Transjordan, Lebanon and Syria. Egypt was the first to conclude an accord with Israel, signing an armistice on February 24. During the following months there were talks with the other Arab states involved in the conflict, with the exception of Iraq. The final accord to be signed was the one with Syria, on July 20.

Despite the talks, there was a return to arms. At the beginning of March, Israeli troops occupied the southern Negev and conquered the city of Eilat and the Gulf of Aqaba. This operation was intended to further strengthen Israel's borders through additional faits accomplis (or 'uvdah in Hebrew, as reflected in the name of this military operation). Egypt did not intervene in defense of the area, which thus passed under Israeli control.

The most significant and difficult accord was that reached between Israel and Transjordan on April 3. The agreed territorial disposition represented a notable modification of UN partition arrangement of November 1947. At the end of complex negotiations, the two states arrived at a compromise on the principal points, which were that the Jordanians should cede to Israel the zone between Qalqilya, Wadi 'Ara and the area to the north of Jenin, while the Hashemite Kingdom would receive a small territory to the south of Hebron. Moreover, a demilitarized strip would be established along the border

136 See Elad Ben-Dror, Ralph Bunche and the Arab-Israeli Conflict: Mediation and the UN, 1947-1949, trans. Diana File and Lenn Schramm (London: Routledge, 2016). 
for about ten kilometers. A special Israeli-Jordanian committee was established to resolve some issues such as access to the Holy Places in Jerusalem and the control of the area around Latrun, but this did not achieve any results.

One of the fundamental features of the accord between Israel and Jordan was the recognition of Jordan's control over Arab Palestine and, thus, the negation of the UN resolution providing for the creation of a Palestinian state. In this sense, the armistice of April 1949 reflects the opportunist logic that had guided the agreement between Golda Meir and King 'Abdullah since 1947.

In the geopolitical reorganization that resulted from the armistice negotiations, the patriarchal diocese of Jerusalem found itself divided between Israel, Jordan $^{137}$ and Egypt, as well as Cyprus. This new phase was redolent with fresh uncertainty. The Latin Catholics of the area were vividly aware of the death of Palestinian hopes, of divisions on the Arab front, and of the dramatic fate of the refugees. Parishioners and clergy had lived through these tragic months of war and expulsions in anxiety and terror. Hundreds of thousands of people had been expelled or had fled as a result of the fighting; there were now about 750,0oo Palestinian refugees. There were no reliable figures on Arab deaths - civilians and combatants - although they probably numbered in the several thousands, while the losses on the Hebrew side were around 5,7005,800 , a quarter of them civilians. The Latin Catholics spent the period from November 1947 to early 1949 in confusion and with a constant, marked feeling of isolation in the absence of a patriarch.

Although Jallad, writing to Cardinal Tisserant at the beginning of May 1948, expressed his certainty that "that the Holy See will not abandon us",138 in reality there was a widespread belief that Rome would forget the Palestinian faithful. The Israeli political and military leadership noted the widespread disappointment with the Holy See shared by a large part of the congregants and clergy during the war; Gorla observed that "even the local Jewish authorities find it very strange". ${ }^{139}$ The Israeli leadership amplified the resonance and scope of this discontent to reinforce the idea that the Vatican was not terribly interested in the fate of the Catholics in the Middle East.

In April 1949, Pius XII published the encyclical Redemptoris Nostri dedicated to the events in Palestine, in which he said that

137 Transjordan changed its name to the Hashemite Kingdom of Jordan on June 2, 1949.

138 APLJ, FC-AG, S. Congregatio Pro E. Orientali, 1919-1953, Jallad to Tisserant, copy, Jerusalem, May 4, 1948, translation from Italian.

139 APLJ, LB-MS, Deir Rafat, Gorla to Girard, Dayr Rafat, September 1948. 
although the actual fighting is over, tranquility or order in Palestine is still very far from having been restored. For We are still receiving complaints from those who have every right to deplore the profanation of sacred buildings, images, charitable institutions, as well as the destruction of peaceful homes of religious communities. Piteous appeals still reach Us from numerous refugees, of every age and condition, who have been forced by the disastrous war to emigrate and even live in exile in concentration camps, the prey to destitution, contagious disease and perils of every sort. ${ }^{140}$

Hughes commented on the document in a letter to the Melkite patriarch, confirming that in the previous weeks he had forwarded to the Holy See the Egyptian government's request that the pope express himself in favor of the internationalization of Jerusalem and the return of the refugees. ${ }^{141}$

Notwithstanding the appeals to Rome, in Jerusalem the end of armed conflict inaugurated a new phase in the life of the diocese. It was now faced with the difficult task of reconstruction and with new political actors. Above all, however, was the complex problem of defining the nature of the humanitarian and pastoral activity for the Palestinian refugees.

\footnotetext{
140 AAS 41 (1949): 162.

141 AMCP, Internonciature apostolique Egypte, 1902-1957, Hughes to Maximos IV, al-Zamalik, Cairo, April 17, 1949.
} 